\title{
Memlükler Döneminde Bir İlim Kurumu: İbn Tolun Camii ve Ulemaya Sunduğu Mansiplar*
}

\author{
Muhammet Enes Midilli**
}

\begin{abstract}
Memlükler döneminde Kahire, ulemaya dersler ve mansıplar sunan çok sayıda ilim kurumuna ev sahipliği yapmıştır. Bu dönemde şehirdeki bazı büyük camiler, sultanların ve yüksek dereceli emîrlerin kurdukları vakıflar sayesinde vakıf-temelli birer ilim kurumu haline gelmiştir. Bu camilerin erken örneklerinden biri olan İbn Tolun Camii, VII. (XIV.) asrın sonunda dönemin Memlük sultanı tarafından yeniden imar ettirilmiştir. Camiyi Memlükler döneminin önde gelen ilim kurumlarından biri haline getiren vakıf da bu imar faaliyeti sırasında kurulmuştur. Cami vakfiyesinin dersler ve mansıp sahipleriyle ilgili şartları içeren bölümleri bu makalenin konusunu oluşturmaktadır. Memlükler döneminde İbn Tolun Camii’nde dört fıkıh mezhebinin her biri için derslerin yanı sıra tefsir, hadis, tıp, mîâd, kıraat ve nahiv dersleri düzenlenmekteydi. Camide ulemaya fikıh müderrisi, muîd, tefsir şeyhi, hadis şeyhi, nakib, tıp müderrisi, mîâd şeyhi, münşid/mâdih, kıraat ve nahiv mütesaddiri, mülakkın, şeyhüssübha, müsebbih/ zâkir, hatip, imam, reîsülmüezzinîn, müezzin, kāri, müeddip, arîf, hâzinülkütüp ve saâtî gibi eğitimle ve dinî vazifelerle ilgili çok sayıda mansıp tahsis edilmiştir. Makalede, vakfiye merkeze alınarak bu mansıpların mahiyetleri tespit edilmeye çalışılmış, bu sırada Memlük Kahiresi’ndeki ilim kurumlarının günümüze ulaşan vakfiyeleri, Memlük kaynaklarındaki bilgiler ve mansıpların tanımlarıyla ilgili modern literatürde yer alan tartışmalar da dikkate alınmıştır. Makalede ayrıca dört fıkıh mezhebinin yanında birden fazla ilmin tedris edildiği çok mansıplı ilim kurumlarının teşekkülü hakkında bilgi verilerek İbn Tolun Camiỉnde görülen ilim kurumu modelinin tarihî bağlamı tespit edilmeye çalışılmıştır.
\end{abstract}

Anahtar Kelimeler: İbn Tolun Camii, cami, vakfiye, mansıp, ulema, medrese, Kahire, Memlükler.

* Araştırmacı Yetiştirme Projesi (AYP) çerçevesinde sunduğu katkılardan dolayı Türkiye Diyanet Vakfı İslam Araştırmaları Merkezi yönetimine, proje kapsamında bu makalenin yazım aşamalarını takip eden ve titizlikle metni okuyup katkıda bulunan Doç.Dr. Berat Açıl’a, kıymetli önerileriyle makalenin olgunlaşmasını sağlayan Doç.Dr. Halit Özkan, Dr. Öğr. Üyesi Harun Yilmaz ve Dr. Öğr. Üyesi Halil İbrahim Hançabay’a teşekkür ederim.

** Arş.Gör., İstanbul Üniversitesi İlahiyat Fakültesi, ORCID oooo-ooo3-0145-3987 enesmidilli@istanbul.edu.tr 


\section{Giriş}

Memlükler döneminde ulemanın sosyal tarihi, ilmî mansıpların ve bu mansıpların kendileri üzerinden vazedildiği ilim kurumlarının tarihi ile yakından ilişkilidir. Erken Memlük döneminde Kahire camilerinin vakıflarla desteklenen birer ilim kurumu hüviyeti kazanmaya başladıkları görülmektedir. Bu camilerden biri olan İbn Tolun Camii'nin Memlükler döneminde kurulan vakfı, vakfiyede ulemaya tahsis edilen mansıplar, bu mansıpların tanımları, mansıplarla dersler ve ilimler arasında kurulan ilişki ve mansıpların ulemanın ilmî ve meslekî hayatına muhtemel etkileri bu makalenin konusunu oluşturmaktadır. Bu bağlamda çalışmada, Memlükler döneminde ulemaya sunulan mansıpların, İbn Tolun Camii'de yer alan mansıplar üzerinden incelenmesi de hedeflenmektedir.

Makalede öncelikle İbn Tolun Camii’nin Memlükler döneminde yeniden imar edilmesi, bu imar faaliyeti sırasında cami için kurulan vakıf, bu vakfın günümüze ulaşan vakfiyesi ve vakfiyede dersler ve mansıplar hakkında belirlenen şartlar hakkında bilgi verilecektir. Ardından camideki mansıpların sayısı, çeşitliliği ve mansıp sahiplerinin tahsisatı dikkate alınarak caminin, Kahire'de bulunan ilim kurumları arasındaki yeri ve önemi tespit edilmeye çalışılacaktır. Bu bağlamda İbn Tolun Camii’nde görülen, dört fikıh mezhebi ve beraberinde birden fazla ilmin tedris edildiği, ulemaya çok sayıda mansıp sunan ilim kurumu modelinin teşekkül süreci de değerlendirilecektir. Camilerin, ele alınan dönemde Kahire’de, vakıflar aracılığı ile ulemaya mansıplar sunan prestijli ilim kurumları haline geldiği tezi, bu makalenin temel iddiasını oluşturmaktadır.

İslam tarihinde ilim kurumları arasında caminin yeri nedir, bu kurumların tarihî serüveninde bir ilim kurumu olması bakımından caminin konumunda bir değişiklik meydana gelmiş midir, cami ile başta medrese olmak üzere diğer ilim kurumları arasında nasıl bir ilişki vardır ve zaman içerisinde farklı bölgelerde bu ilişkinin mahiyetinde değişiklikler olmuş mudur gibi sorular, İslam ilim kurumlarıyla ilgili modern literatürde -çoğu zaman doğrudan olmasa da- tartışmaya dahil edilmiştir. Johannes Pedersen, Encyclopaedia of Islam'ın birinci edisyonu için yazdığı "Masdjid" maddesinde, başta medrese olmak üzere İslam dünyasında ortaya çıkan ilim kurumlarının temel özellikleri bakımından camilerle tamamen aynı olduklarını ileri sürmüştür. Ona göre medreselerde ibadet yapılan mekânlar, camilerde ise öğrencilerin ders yapabildikleri ve konaklayabildikleri alanlar bulunmaktaydi. ${ }^{1}$ Camilerde olduğu gibi medreselerde de vaaz verildiği ve içinde minber

1 Pedersen, “Masdjid", s. 354. 
bulunan yani cuma hutbesi verilen medreselerin bulunduğu bilinmektedir. ${ }^{2}$ Pedersen, bütün ilim kurumlarını bir şekilde cami ile irtibatlandırır ve buna uygun olarak, "Bir Eğitim Merkezi Olarak Cami” başlığı altında medrese ve medreseye benzer kurumlar dediği hankah, ribat, bîmaristan, mektep, küttap ve kütüphane gibi kurumların işlevleri ve mimari formları bakımından cami olma vasfını sürdürdüklerini, camilerin de çeşitli şekillerde bu kurumların işlevlerini yerine getirdiklerini savunur. ${ }^{3}$

George Makdisi, medrese tarihine dair yapılmış en önemli çalışmalardan biri sayılan The Rise of Colleges'ta, Pedersen'in yukarıda belirtilen görüşlerini değerlendirir ve onun medrese ile cami arasında hiçbir fark görmemesini, asıl ilgi alanının "medrese-cami" niteliğindeki Kahire camileri olmasına bağlar. Makdisi'ye göre Kahire'deki pek çok caminin asıl işlevi, öncelikle bir eğitim kurumu, ardından cuma namazlarının kılındığı bir ibadethane olarak hizmet vermektir. Şehirde çok sayıda cami bulunmasının temel sebebi de budur. ${ }^{4}$ Makdisi aslında, medresenin kuruluşu, idarî kontrolü ve müfredatı bakımından camiden farklı bir kurum olduğunu düşünmekteydi. ${ }^{5}$ Buna rağmen Kahire söz konusu olduğunda bu şehirdeki camilerin pek çoğunun "medrese-cami" niteliği taşıdığını ifade etmekte, ancak "medrese-cami" ifadesiyle neyi kastettiğini yeterince açıklamamaktadır.

2 Pedersen, bir caminin çevresinde ders yapılmak üzere ayrılan bir odanın ya da cami içindeki bir halkanın zaman zaman medrese olarak isimlendirilebildiğini söyler. Medrese ya camiye bağlı olarak caminin çevresinde yer alır ya da şayet camiden uzak bir konumda inşa edilmişse bu durumda sahip olduğu ibadet mekânı ve hutbe okunan minberi ile kendisi bir cami işlevi görürdü. Dolayısıyla ona göre her iki durumda da medresenin camiden farklı bir kurum olduğu söylenemez (Pedersen, "Masdjid”, s. 357-58).

3 Buna göre örneğin bir hankahın temel gayesi sûfîlere konaklayacakları ve zikir yapabilecekleri bir mekân sunmaktır. Ancak namaz kılmaya tahsis edilmiş alanlara sahip olması ve bazı örneklerinde görüldüğü üzere cuma hutbesi verilen bir minbere sahip olması bakımından hankah da aslında bir camidir (Pedersen, "Masdjid", s. 359).

4 Makdisi, The Rise of Colleges, s. 20-21. Ancak Makdisi, Pedersen'in tezini kabul etmez ve medrese ile caminin temelde aynı kurumlar olarak görülmesi halinde ikisinin hususiyetlerinin belirsiz hale geleceğini söyler (Makdisi, The Rise of Colleges, s. 305; tercümesi için bk. Makdisi, Ortaçağ’da Yüksek Öğretim, s. 433).

5 Makdisi'ye göre caminin aksine medresenin kuruluşu vakfa dayanır ve medresede bulunan tek kürsüye vâkıfın belirlediği bir âlim müderris olarak atanır. Camideki bir halkanın müderrisliğine ise atama bizzat halife tarafından yapılır (Makdisi, "Onbirinci Yüzyıl Bağdad’ında İslâm Eğitim Müesseseleri”, s. 206-207, 218). Dolayısıyla halifenin yetki sahası içinde olan camiyi "yönlendirmek" söz konusu değildir, fakat doğrudan vâkıfın iradesiyle yönetilen medreseler şahısların "siyasî icraatlarının bir aracı" olarak kullanılabilir (Makdisi, “Onbirinci Yüzyıl Bağdad’ında İslâm Eğitim Müesseseleri”, s. 253). Müfredat bakımından ise medrese, Makdisi’ye göre dinî ilimlerin en önemlisi olan fikıh ilmine tahsis edilmiş bir kurumdur, camide ise bu ilimlerin tamamı için çok sayıda kürsü bulunur (“Onbirinci Yüzyıl Bağdad’ında İslâm Eğitim Müesseseleri”, s. 249). 
Pedersen ve Makdisi'nin çalışmaları, Kahire'de caminin önemli bir ilim kurumu olduğunu ima etmenin ötesinde konuyla ilgili kaynakların ayrıntılı bir incelemesini içermez. Memlük Kahiresi’nde caminin bir ilim kurumu olarak sahip olduğu hususiyetler, Jonathan Berkey tarafından daha ayrıntılı bir şekilde incelenmiştir. Ona göre vakıflar aracılığı ile düzenli derslerin yapıldığı ilim kurumlarını medrese ile sınırlandırmak mümkün değildir. Bilginin elde edilmesini, aktarılmasını ve bu süreçteki aktörler olan âlimleri konu edinen çalışmalar, medrese dışındaki kurumları da dikkate almak durumundadır. ${ }^{6}$

Berkey'e göre tedris edilen ilimler ve derslerde takip edilen usuller bak1mından cami ve medrese gibi kurumları birbirinden ayırt etmek mümkün değildir. Zira hem camide hem medresede tedris edilen ilimler aynıdı ve dersler her iki kurumda da aynı âlimler tarafından verilmekteydi. Bir başka deyişle her iki kurumda da müderrislik yapan âlimler aynı havuzdan seçilmekteydi. ${ }^{7}$ Bilginin aktarılmasında takip edilen usul ve bir ilim dalında ihtisas sahibi kabul edilmenin şartları bakımından ise eğitim, hocatalebe ilişkisine dayanmaktaydı. Onun ifadeleriyle Memlükler döneminde Kahire’de eğitim, "loci”ye (kurum) değil "personae”ye (belirli bir hoca) bağlıdır ve kurumların eğitim süreçlerinde bir tekel oluşturması söz konusu değildir. ${ }^{8}$

Berkey, Memlükler dönemi boyunca Kahire'de, içerisinde dersler için mekân sağlayan ve bununla yetinmeyip hocalar ve talebeler için maaşlar sunan çok sayıda caminin kurulduğunu özellikle vurgular. Ezher Camii, Amr b. Âs Camii, Hâkim Camii, İbn Tolun Camii, Mâridânî Camii, Hatîrî Camii, Aksungur Camii gibi camilerde vakıflarla desteklenen dersler ve ulemaya sunulan mansıplardan örnekler verir. Bu kurumların ya kuruluşlarından itibaren ya da daha sonra bir vâkıfın teşebbüsü ile İslamî ilimlere dair düzenli ve vakıflarla desteklenen dersler sunduklarını ve bu şekilde giderek medrese ile benzerlik göstermeye başladıklarını savunur. ${ }^{9}$ Berkey’nin çalışması, Memlük Kahiresinnde bir ilim kurumu olarak camiye dair kısa bir inceleme içermesine rağmen cami-vakıf ve cami-medrese ilişkilerine dair önemli bir çerçeve sunmaktadır.

Memlükler dönemi ilim kurumlarını ele alan Arapça modern çalışmalar içerisinde Abdülganî Mahmûd Abdülâtầnin, Eyyûbîler ve Memlükler

6 Berkey, The Transmission of Knowledge, s. 50; kitabın Türkçe tercümesi için bk. Berkey, Ortaçă̆ Kahire’sinde Bilginin İntikali, s. 66.

7 Berkey, The Transmission of Knowledge, s. 54.

8 Berkey, The Transmission of Knowledge, s. 23, 50.

9 Berkey, The Transmission of Knowledge, s. 51-54. 
döneminde Kahire'de ilim kurumlarını incelediği çalışması, camilere özel bir yer ayırması bakımından önem arzetmektedir. Abdülâtî, medrese inşasına daha fazla önem vermeleri sebebiyle Eyyûbîler döneminde Misır'da camilerin nisbî bir ihmale maruz kaldıklarını ileri sürmektedir. Ona göre Memlükler döneminde bir ilim kurumu olarak camilere verilen önem artmış, bu bağlamda camilerde dersler ikame edilerek müderrislere ve öğrencilere maaşlar tahsis edilmiştir. ${ }^{10}$ Muhammed Muhammed Emîn ise Memlükler döneminde Mısır vakıflarını incelediği çalışmasında İbn Tolun Camii, Amr b. Âs Camii ve Ezher Camii gibi büyük camilerin ilmî şöhretlerini muhafaza etmek adına dönemin sultanları ve emîrleri tarafından bu camilere dersler vakfedildiğini, bu derslere katılan müderris ve öğrencilere de maaşlar tahsis edildiğini ifade etmektedir. ${ }^{11}$ Memlükler'in son asrında Kahire'de hadis ilminin tedrisi, muhaddisler ve hadis literatürünü konu edindiği çalışmasında Halit Özkan, hadis derslerinin yapıldığı mekânlar arasında camileri de incelemiş ve camilerde yapılan hadis derslerinden ve bu dersleri veren muhaddislerden örnekler vermiştir. ${ }^{12}$

Buraya kadar ele alınan çalışmaların temel amacı, Memlükler döneminde Kahire'de vakıf-temelli bir ilim kurumu olarak camiyi incelemek değildir. Onların bu konuya katkısı, Kahire'de, özellikle de Memlükler döneminde caminin, ibadet yapılan bir mekân olmanın ötesinde eğitimle ilgili işlevlere sahip olduğuna dikkat çekmek olmuştur. Bu çalışmalarda cami vakfiyelerinin ayrıntılı bir incelemesine yer verilmemiş, bu vakfiyelerin dersler ve mansıp sahiplerine ilişkin şartları yeterince değerlendirilmemiştir. Bu konuları ve Memlük Kahiresinde caminin, nasıl vakıflar yoluyla ulemaya dersler ve mansıplar sunan bir ilim kurumu haline geldiğini İbn Tolun Camii ve vakfiyesi üzerinden incelemek mümkündür.

\section{İbn Tolun Camii'nin Tarihi: İnşa, İhmal ve Yeniden İmar}

İbn Tolun Camii, Abbâsîler tarafından vali vekili olarak gönderildiği Misır'da müstakil bir devlet kuran Ahmed b. Tolun (254-270/868-884) tarafından 265 (879) yllında inşa ettirilmiştir. Ahmed b. Tolun, kurucusu olduğu Tolunoğulları Devleti’nin başşehri olarak Fustat'in kuzeydoğusuna Katâi‘

10 Abdülâtî, et-Ta 'lìm fî Mısr, s. 209-10.

11 Emîn, el-Evkäf, s. 259-61.

12 Özkan, Memlüklerin Son Asrında Hadis, s. 55-6o. Semâ kayıtlarından hareketle D1maşk'ta bulunan Muzafferî Camii’nde Memlükler döneminde düzenlenen hadis derslerini ve bu derslerde kadınların okuttukları eserleri inceleyen bir çalışma için bk. Emiroğlu, "Kadınların Hadis Okuttuğu Mekânlar", s. 33-70. 
şehrini kurmuş ve bu şehrin merkezine kendi ismiyle anılan camiyi inşa ettirmiştir. ${ }^{13}$

İbn Tolun Camiỉnin inşa edildiği Katâii şehri, Mısır'da Abbâsî hâkimiyetini yeniden tesis etmek üzere 292 (905) yılında bölgeye gönderilen Abbâsî ordusu tarafından yerle bir edilirken şehirden geriye sadece caminin kaldığ ifade edilmektedir. ${ }^{14}$ Tolunoğulları Devleti’nin son bulması ve Katâí şehrinin tamamen yıkılmasıyla birlikte etrafında meskûn bir nüfus kalmayan cami ihmal edilmiş ve uzun bir süre metrûk vaziyette kalmıştır. ${ }^{15}$ Makrîzî (845/1442), Fâtımî halifelerinden Müstansır-Billâh döneminde (427-487/ 1036-1094) Katâii şehrinin harap vaziyette olduğunu, burada yaşayan bir nüfusun bulunmadığını, çoğu bölümü harap olan İbn Tolun Camii’nin de Mağripli hacıların Mısır'dan geçerken develeriyle birlikte konakladıkları bir mekân olarak kullanıldığını ifade etmektedir. ${ }^{16} \mathrm{Bu}$ tarihten yaklaşık bir asır sonra Eyyûbî hâkimiyetindeki Mısır’a gelen İbn Cübeyr de seyahatnamesinde, sultanın camiyi konaklamaları için Mağripli yolculara tahsis ettiğinden bahsetmektedir. ${ }^{17}$

Tolunoğulları dönemindeki ihtişamlı günlerinden yaklaşık dört asır sonra İbn Tolun Camiỉnin yeniden imarı ve çevresindeki bölgenin yeniden mamur hale gelmesi Memlükler döneminde gerçekleşecektir. Bu dönemde caminin bulunduğu Fustat ve Kahire arasındaki bölgede meskûn alanların arttı̆̆ı, çok sayıda binanın bulunduğu ve dönemin nüfuzlu emîrlerinin burada ikamet ettiği ifade edilmektedir. ${ }^{18}$ Ayrıca ele alınan dönemde şehrin bu bölgesinde İbn Tolun Camii dışında çok sayıda cami, mescit, medrese, hankah ve türbe gibi yapının inşa edildiği bilinmekte, ciddi bir nüfus artışı olduğu

13 Belevî, Sîretü Ahmed b. Tolun, s. 182-83; İbn Abdüzzâhir, er-Ravzatü'l-behiyye, s. 76-81; İbn Dokmak, el-İntisâr, IV, 122-23; Behrens-Abouseif, "İbn Tolun Camii”, s. 416. İbn Tolun Camii'nin mimari tarihi üzerine çalışmalar yapan Tarek Swelim, Ahmed b. Tolun'un Sâmerrâ şehrinde yetiştiğine dikkat çektikten sonra onun Mısır'da toplum nazarında meşruiyet kazanmak ve Mısır’ Abbâsî vilayetinden müstakil bir devlete dönüştürmek için çabaladığını iddia etmektedir. Dolayısıyla ona göre mimarisinde Sâmerrâ üslubundan izler taşıyan İbn Tolun Camiỉnin inşass, Ahmed b. Tolun'un bu siyasi programının bir parçası olarak değerlendirilmelidir (bk. Swelim, Ibn Tulun, s. 89).

14 İbn Dokmak, el-İntisâr, IV, 121; Makrîzî, el-Hıtat, II, 104.

15 Swelim, Ibn Tulun, s. 135.

16 Makrîzî, el-Hıtat, IV/1, s. 74. Bununla birlikte Fâtımîler döneminde caminin bazı mimari birimlerinin yenilendiğine dair kayıtlar ve kalıntılar bulunmaktadır (ayrıntılı bilgi için bk. Behrens-Abouseif, "İbn Tolun Camii”, 417; Swelim, Ibn Tulun, s. 142-49).

17 İbn Cübeyr, Rihle, s. 26-27.

18 İbn Fazlullah el-Ömerî, Mesâlikül-ebsâr, III, 423; İbn Dokmak, el-İntisâr, IV, 121; Kalkaşendî, Subhu'l-a ş̧â, III, 40, 405, 409; Makrî̀î, el-Hıtat, II, 209-10; İbn Tağrîberdî, en-Nücûmüzz-zâhire, IX, 198. 
tahmin edilmektedir. ${ }^{19}$ Dolayısıla caminin yeniden imarının, Kahire'nin Memlükler'in hâkimiyetinde yaşadığı genişleme ve geçirdiği dönüşümle yakından irtibatlı olduğu söylenebilir. Neticede 696 (1296) yılında dönemin Memlük sultanı el-Meliküll-Mansûr Hüsâmeddin Lâçin (1296-1299) kendi hazinesinden tahsisatta bulunarak İbn Tolun Camiỉni yeniden imar ettirmiş $^{20}$ ve bu sayede cami, orijinal mimari formuyla günümüze kadar ulaşabilmiştir. $^{21}$

Sultan Lâçin, caminin imarı işine ve kurulacak vakfa nezaret etmesi için emîrlerinden birini görevlendirmiş ve bu iş için gereken bütün masrafları kendi hazinesinden karşılamıştır. Emîre caminin giderleri için gerekli olan mülkleri satın almasını emretmiş, o da Cîze bölgesindeki bir arazi ile İbn Tolun Camii yakınındaki bir araziyi satın alarak bunlardan elde edilecek geliri, caminin ve vakfının giderlerine tahsis etmiștir. $\mathrm{H}_{1 t a t}{ }^{22}$ müelliflerinden İbn Dokmak (ö. 809/1407), caminin onarımının ve yeniden imarının son derece özenli bir şekilde yapıldığını ifade ederken Makrîzî, imar masraflarının yaklaşık yirmi bin dinarı bulduğunu kaydetmiştir. ${ }^{23}$ Ayrıca bu imar faaliyeti esnasında cami için bir vakıf kurulmuş, vakfiyede camiye tahsis edilen dersler ve mansıplar belirlenmiş ve bu vakıf, İbn Tolun Camiỉnin Kahire'deki en önemli ilim kurumlarından biri haline gelmesine imkân sağlamıștır.

\section{İbn Tolun Camii Vakfiyesi}

İbn Tolun Camii’nin vakfiyesi ve Memlükler döneminde Kahire'de bulunan bazı ilim kurumlarının vakfiyeleri günümüze ulaşmıştır. ${ }^{24}$ Haarmann’ın da ifade ettiği üzere bu vakfiyeler, VII (XIV) ve VIII. (XV.) yüzyılda Mısır’da

19 Raymond, "al-Maqrīzīs Khitat", s. 152-55.

20 Baybars el-Mansûrî, Zübdetü'l-fikre, s. 315; Safedî, el-Vâfî, XXIV, 291; İbn Dokmak, en-Nüfhatül-miskiyye, s. 101; a.mlf., el-İntisâr, IV, 124; Makrî̀î, el-Hitat, IV/1, s. 7678; Aynî, İkdü'l-cümân, III, 36o. İmar işleri devam ederken Kahire'de bulunan ve İbn Tolun Camii’ni ziyaret eden Kāsım b. Yûsuf et-Tücîbî (ö. 730/1329) seyahatnamesinde, caminin imarı için büyük mallar infak edildiğinden ve çok sayıda işçinin çalıştığından söz etmektedir (Tücîbî, Müstefâdür-rihle, s. 7).

21 Memlükler döneminde gerçekleştirilen imar faaliyetinin ayrıntıları ve caminin mimari tarihi için önemi hakkında bk. Swelim, Ibn Tulun, s. 163-94.

22 Hıtat ismi, bir şehrin topografyası, tarihî coğrafyası, mahalleleri, bina ve yapıları hakkında bilgi veren eserlere verilmektedir (Yiğit, "Hıtat", s. 401-402).

23 İbn Dokmak, el-İntisâr, IV, 124; Makrîzî, el-Hitat, IV/1, 76-98.

24 Memlükler döneminden günümüze ulaşan ve bugün Misır'da Dârü’l-vesâiki'lkavmiyye ve Vizâretü'l-evkāf'ta bulunan vakfiyelerin Muhammed Muhammed Emîn tarafından hazırlanan katalogu için bk. Emîn, Fihristü vesâiki'l-Kähire. Bu vakfiyeler üzerine yapılan çalışmaların durumu hakkında bk. Emîn, el-Evkāf, s. 6-8; Little, "The Use of Documents", s. 11; Shaaban, Piety and Power, s. 12-17. 
bulunan eğitim kurumlarının ekonomik ve sosyal tarihi için muhtemelen en tafsilatlı ve doğru bilgileri sunan belgelerdir. ${ }^{25}$ Memlükler döneminden önce hiçbir zaman ve coğrafyadan bu miktarda vakfiyenin günümüze ulaşmadığ 1 dikkate alındığında bu vakfiyelerin ilim kurumlarının düzen ve işleyişine dair sunduğu bilgilerin değeri daha da artmaktadır. ${ }^{26} \mathrm{Bu}$ vakfiyelerde yapının mimari birimleri ayrıntılı bir şekilde tavsif edilerek fiziksel sınırları belirlenmekte, kuruma gelir getirmesi için vakfedilen arazi ve mülkler sıralanmakta, mansıp sahipleri ve diğer hizmetlerle ilgilenen görevlilerin alacakları aylık tahsisat ve erzak belirlenmekte, mansip sahiplerinde bulunması gereken yeterlilikler ve onların görevleri ayrıntılı bir şekilde kaydedilmektedir. ${ }^{27}$ Bazı örneklerde ilim kurumlarında hangi mezhebin ya da mezheplerin fıkhının tedris edileceği, müderris ve öğrenci sayılarının ne kadar olacağı, derslerin hangi gün ve saatlerde yapılacağ ${ }_{1}$ ve hatta hangi kitapların okunacağı ile ilgili kayıtlar bulunabilmektedir. ${ }^{28}$

Mesela İbn Tolun Camiỉnin bitişiğinde, 757 (1356) yılında inşa edilmiş olan Sargatmışiyye Medresesỉnin vakfiyesinde önce vâkıf hakkında bilgi verilmiş, ardından medresenin mimarisi ayrıntılı bir şekilde tavsif edilmiş ve medreseye vakfedilen mülkler kaydedilmiştir. Medreseye tahsis edilen müderris, muîd, şeyhülhadis, hâzinülkütüp gibi mansiplar, mansip sahiplerinin sayısı, aylık tahsisatı tek tek sıralanmış; imam, müezzin, kāri, bevvap, ferraş gibi diğer vazife sahipleri hakkında da bilgi verilmiştir. Müderrislerde aranan niteliklere, tedris usulüne, derslerin haftanın hangi günleri ve günün hangi saatlerinde yapılacağına dair şartlar da ayrıntılı bir şekilde kayıt altına alınmıştır. ${ }^{29}$

İbn Tolun Camiỉnin vakfiyesi de günümüze ulaşmış olup Kahire’de Dârü'l-vesâiki'l-kavmiyye'de muhafaza edilmektedir. ${ }^{30}$ Bunun yanında Memlükler döneminde telif edilen hitat, tarih, tabakat ve seyahatname türü eserlerden bazıları muhtasar olarak bu vakfiyeden bahsederken vakfiyede yer alan dersler ve mansıplar hakkında da bilgi vermişlerdir. ${ }^{31}$

\footnotetext{
25 Haarmann, "Mamluk Endowment Deeds", s. 31.

26 Berkey, The Transmission of Knowledge, s. 15-16.

27 Haarmann, "Mamluk Endowment Deeds", s. 33-35.

28 Emîn, el-Evkāf, s. 244-49.

29 İbrâhim, "Nassân cedîdân", s. 133, 147-52.

30 Vakfiyyetü Hüsâmeddîn Lâ̧̧în, nr. 3/17, 18. Muhammed Muhammed Emîn’in de belirttiği üzere, üzerinde bulunan yanmış ve yırtık bölümler sebebiyle vakfiye belgesi önemli ölçüde tahrip olmuş durumdadır (Emîn, Fihristü vesâikı'l-Kāhire, s. 7). Vakfiyenin bir nüshasını temin etmemi sağlayan Tarek Swelim ve Muhammad Shaaban’a teşekkür ederim.

31 Baybars el-Mansûrî, Zübdetü̉l-fikre, s. 315; Tücîbî, Müstefâdür-rihle, s. 7; Nüveyrî, Nihâyetüll-ereb, XXXI, 203; Safedî, A'yânü'l-asr, IV, 171; İbn Dokmak, el-İntisâr, IV, 124;
} 
Vakfiyede, vakfın kuruluş tarihi 21 Rebîulâhir 697 (5 Şubat 1298) olarak kaydedilmiştir. Vâkıfın, el-Melikü’l-Mansûr Hüsâmeddin Lâçin olduğu ifade edildikten sonra vakfın nâzırlığına Emîr Alemüddin Sencer ed-Devâdârînin tayin edildiği belirtilmiştir. ${ }^{32}$ Ardından Cîze bölgesinde yer alan Münyetü Andûne ${ }^{33}$ arazisinin gelir getirmek üzere camiye vakfedildiği kayıt altına alınmıştır. Ayrıca caminin sınırları ayrıntılı bir şekilde belirtilmiş, caminin mimari birimleri ve bunların işlevleri ile ilgili bilgilerin yanı sıra caminin güvenliği, temizliği ve bakımıyla ilgilenmek üzere tayin edilen bevvap, sathî, ferraş ve kayyım gibi görevlilerle ilgili şartlar da kayıt altına alınmıştır. ${ }^{34}$ Vakfiyenin Memlük Kahiresi’nde ilim kurumlarındaki işleyişin ve ulemanın ilmî pratiklerinin tespiti için önem arzeden bölümü ise camideki dersler ve ilmî mansıplara dair şartları ihtiva eden kısımlarıdır.

\section{İbn Tolun Camii'nde Ulemaya Tahsis Edilen Mansiplar ve Dersler}

Memlükler döneminde İbn Tolun Camii’nde ulemaya fikıh müderrisi, muîd, tefsir şeyhi, hadis şeyhi, nakib, tıp müderrisi, mîâd şeyhi, münşid, kıraat ve nahiv mütesaddiri, mülakkın, şeyhüssübha, müsebbih/zâkir, hatip, imam, reîsülmüezzinîn, müezzin, kāri, müeddip, arîf, hâzinülkütüp ve sââtî olmak üzere çok sayıda mansıp tahsis edilmiştir. ${ }^{35}$

Makrîzî, el-Hitat, IV/1, s. 78-79; a.mlf., es-Sülûk, II, 279; Aynî, İkdül-cümân, III, 359-60; İbn Tağrîberdî, el-Menhelüs-sâfî̀, VI, 72; Süyûtî, Hüsnüll-muhâdara, II, 250; İbn İyâs, Bedâiu'z-zühûr, I/1, s. 395.

32 Vakfiyyetü Hüsâmeddîn Lâçîn, nr. 3/18. Nüveyrî, Nihâyetü'l-ereb, XXXI, 203; Makrîzî, es-Sülûk, II, 279. Emîr Alemüddin Sencer, sultan tarafından Dımaşk'tan Kahire’ye çağırılmış, kendisine dârüladl nâipliği yanında İbn Tolun Camiỉnin nâzırlığı görevi tevdi edilmiştir (Aynî, İkdü'l-cümân, III, 360). Emîr Sencer'in dindar ve âlim bir zat olduğu, fikıh ve hadis ilimleri ile iştigal ettiği ve huzurunda ilmî müzakerelerde bulunan ulemaya ikramda bulunduğu ifade edilmektedir (Zehebî, Mu'cem, s. 219-20).

33 Nil nehrinin batı tarafındaki Cîze topraklarında yer alan Münyetü Andûne arazisinin İbn Tolun Camii'nin vakfı olduğu bilgisi, İbnü’l-Ceyân (885/148o) tarafından da kayıt altına alınmıştır. İbnü'l-Ceyân eserinde Mısır'da 777 (1376) yılında yapılan arazi tahririni kayıt altına almış, burada hangi arazinin kime iktâ edildiği, hangi arazinin nereye vakfedildiği gibi bilgilere yer vermiştir. Bu kayıtlardan hareketle vakfiyede belirtilen arazinin, vakfın kuruluşundan yaklaşık bir asır sonra vakıf mülkü olma özelliğini sürdürdüğünü söylemek mümkündür (bk. İbnü’l-Ceyân, et-Tuhfetüsseniyye, s. 146).

34 Vakfiyyetü Hüsâmeddîn Lâçîn, nr. 3/17, 18; Tücîbî, Müstefâdürr-rihle, s. 3-4; Nüveyrî, Nihâyetüll-ereb, XXXI, 203; Makrîzî, es-Sülûk, II, 279; a.mlf., el-Hitat, IV/1, s. 78; Abdülâtî, et-Ta'lìm fî̀ Misr, s. 226-30.

35 Makalede mansıplar sıralanırken vakfiyede yer alan sıralama esas alınmıştır. Mansıpların mahiyeti hakkında ilerleyen bölümlerde bilgi verilecektir. 
Cami vakfiyesinde mansıpların mahiyeti, mansıp sahiplerinin vasıfları, görevleri ve tahsisatı ile ilgili bilgiler yer almaktadır. Ayrıca Memlükler döneminde Kahire'de bulunan bazı ilim kurumlarının günümüze ulaşan vakfiyeleri ve doğrudan mansıplar hakkında bilgi veren dönemin bazı kaynakları, mansıplar hakkında İbn Tolun Camii’nin vakfiyesinde verilen bilgilerin mukayese edilmesine imkan sağlamaktadır. Caminin vakfiyesi esas alınmakla birlikte bahsi geçen diğer kaynaklarda bulunan bilgilerin ve modern literatürde yer alan ilmî mansıpların tanımları ve işlevleri ile ilgili farklı yaklaşımların değerlendirilmesi, Memlükler döneminde İbn Tolun Camii’nde ulemaya sunulan mansıpların mahiyetinin ve derslerle ilgili ilmî pratiklerin daha iyi anlaşılmasına katkı sağlayabilir.

\section{Fıkıh Müderrisi, Muîdleri ve Öğrencileri}

Vakfiyede İbn Tolun Camii’ne dört fikıh mezhebinin her biri için bir müderris, iki muîd ve otuz öğrenci tayin edilmiş, ${ }^{36}$ fikıh derslerinin bu konuda âdet olduğu üzere güneşin doğuşu ile zeval vakti arasında yapılması kararlaştırılmıştır. Vakfiyedeki şartlara göre fikıh dersinin müderrisi, mezhebinin görüşlerine ve istikrar kazanmış usullere (er-resmül-mu'tâd) uygun olarak ders vermeli, mezhebinin delillerini (edille ve berâhîn) ve öğrencilerin anlamakta zorlandıkları hususları onlara izah etmelidir. Ayrıca müderristen, öğrencileri seviyelerine uygun olacak şekilde usûl-i fikıh ve fürû-1 fikıhta ezber ve araștırma ile vazifelendirmesi istenmektedir. Flkıh dersindeki muîdlerin görevi ise müderrisin ele aldığ konuyu, özellikle de anlaşılması zor, müphem ve kapalı hususları nasıl şerhettiğini dikkatle takip etmek ve öğrencilerin ders esnasında anlayamadıkları hususları onlara açıklamaktır. ${ }^{37}$

Cami vakfından dört fikıh mezhebinin müderrislerinden her birine aylık 200 dirhem, muîdlerden her birine ise aylık 80 dirhem tahsis edilmiştir. Her bir fikıh mezhebinin dersi için tayin edilen otuz öğrenciye ise aylık toplam 500 dirhem verilmesi kararlaştırılmıştır. Müderris, bu miktarı ilmî seviyelerine göre öğrenciler arasında paylaştıracak, bunu yaparken her bir öğrencinin aylık 30 dirhemden fazla 10 dirhemden az pay almamasına dikkat edecektir. ${ }^{38}$

36 Vakfiyede fikıh dersleri için belirlenen bu mansıplar dışında 767 (1366) yılında dönemin önde gelen emîrlerinden Yelboğa el-Ömerî tarafından İbn Tolun Camiỉnde görev yapacak yedi Hanefî müderris için 4o'ar dirhem maaş ve erzak tahsis edilmiştir. Kaynaklar, diğer mezheplere mensup olan bir grup fakihin, bu dersin vakıflarından faydalanabilmek için Hanefî mezhebine geçtiklerini kaydetmişlerdir (bk. İbn Kesîr, el-Bidâye, XVIII, 718; Makrîzîi, el-Hitat, IV/1, s. 79; İbn Kādî Şühbe, Târîh, III, 277).

37 Vakfiyyetü Hüsâmeddin Lâç̧în, nr. 3/18; Abdülâtî̀, et-Ta'lìm fî Misr, s. 229.

38 Vakfiyyetü Hüsâmeddîn Lâçîn, nr. 3/18; Abdülâtî, et-Ta'lìm fî̀ Mısr, s. 229. 
Öğrencilere ayrılan tahsisatın paylaştırılması konusunda müderrise verilen bu yetki, ${ }^{39}$ Memlük Kahiresi’nde ilmî pratiğin hoca merkezli karakterini teyit eder niteliktedir. Ancak öğrenciler aleyhine oluşabilecek haksız bir uygulamayı engellemek adına da onların alacakları tahsisat için bir alt ve üst sınır belirlendiği görülmektedir.

\section{Tefsir Şeyhi ve Öğrencileri}

Camide düzenlenecek tefsir dersi için bir tefsir şeyhi ve on beş öğrenci tayin edilmiştir. Vakfiyede tefsir şeyhinden, öğrencilerini tefsirden belirli bölümleri ezberlemekle vazifelendirmesi istenmektedir.

Tefsir dersini veren hocanın, vakfiyede mutlak anlamda "şeyh" olarak isimlendirilmediğini ifade etmek gerekir. Vakfiyenin tefsir dersiyle ilgili bölümünde tefsir dersinin hocası için "şeyhü’t-tefsîr" ibaresi yer alırken mansipların toplu halde sıralandığı bölümde "müderrisü’t-tefsîr" ibaresine yer verilmiştir. ${ }^{40}$ Şeyh Müeyyed Camii’nin vakfiyesinde de tefsir dersini veren hoca "müderrisü’t-tefsîr" adıyla zikredilmiştir. Bu vakfiyeye göre tefsir müderrisinin vazifesi, öğrencilerini Kur’ân-1 Kerim’in tefsiri ve irabı üzerinde çalışmakla görevlendirmek ve anlamakta zorlandıkları hususları onlara açılamaktır. Ayrıca müderrisin, Kur’an tefsirinin yanında Arap dilinde ve irap bilgisinde ihtisas sahibi olması şart koşulmuştur. ${ }^{41}$ İbn Tolun Camiỉnin vakfiyesinde de tefsir dersi ile ilgili şartlar arasında "lügat ve beyana dair muhtasarlar"ın okunmasının şart koşulmuş olması ${ }^{42}$ Memlükler dönemi

39 Vakfiyede yer alan ibare şu şekildedir: "ديصرف كل مدرس لطائفته ما عين لهم على حسب (Vakfiyjetü "درجاتهم عنده" (Vakfiyyetü Hüsâmeddîn Lâç̧în, nr. 3/18).

40 Vakfiyyetü Hüsâmeddin Lâçî̀n, nr. 3/18.

41 Abdül'âtî, "Hüccetü vakfi's-Sultân el-Müeyyed”, s. 336 .

42 Vakfiyyetü Hüsâmeddîn Lâçîn, nr. 3/18. Vakfiyede tefsir dersinin mahiyetiyle ilgili bölümün bir kısmı tahrip olduğu için okunamamaktadır. Ancak șeyhin öğrencileri tefsirden belirli bölümler ezberlemekle yükümlü tutması gerektiğini bildiren bölümün devamında yer alan “lügat ve beyana dair muhtasarlar" (مختصرات اللغة والبيان) ibaresinden öğrencilerin çalışmakla ve ezberlemekle yükümlü oldukları metinler arasında dil ilimlerine dair eserlerin de olduğu anlaşılmaktadır (Vakfiyyetü Hüsâmeddîn Lâç̧in, nr. 3/18). Belagat ilminin bütün konularını ifade etmek üzere bu ilmin tarihî gelişimi sırasında çeşitli isimlerin kullanıldığı bilinmektedir (Kılıç, "Belâgat", s. 381). Vakfiyedeki "beyan" ibaresi de muhtemelen belagat ilminin bütün konularını ifade etmek üzere kullanılmıştır. Muhtemelen bu dersin muhtevasını hem tefsir hem de tefsire dair çalışma yapmanın bir ön şartı olarak kabul edilen dil ve belagat ilimleri oluşturmaktaydı. Bu mansıba tayin edilen âlimlerin neredeyse tamamının dil ilimlerinde meşhur olup bu alanda eserler telif etmiş olmaları bu yorumu desteklemektedir. Erken Memlük döneminde İbn Tolun Camiïndeki tefsir müderrisliği mansıbına tayin edilen âlimler için bk. Midilli, Erken Memlük Döneminde Bir İlmî Müessese, s. 110-119. 
ilim kurumlarında tefsir derslerinin dil ilimleri ile yoğun bir ilişki içerisinde yürütüldügünü göstermesi bakımından dikkat çekicidir.

İbn Tolun Camii’nde görevlendirilen tefsir şeyhine aylık 100 dirhem, öğrencilere ise aylık toplam 250 dirhem ücret tahsis edilmiştir. Fıkıh derslerinde olduğu gibi tefsir müderrisinin bu miktarı, seviyelerine göre öğrenciler arasında taksim etmesi şart koşulmuştur. ${ }^{43}$

\section{Hadis Şeyhi, Muîdi ve Öğrencileri}

Camideki hadis dersi için bir hadis şeyhi, bir muîd ve yirmi öğrenci tayin edilmiş, bu öğrencilerden biri nakib olarak vazifelendirilmiştir. Vakfiyeye göre hadis dersleri günün ilk vaktinde yapılacak, hadis şeyhi her bir ders günü için öğrencileri bir hadis ezberlemekle vazifelendirecektir. Muîdin görevi ise öğrencilerin hadisi doğru şekilde ezberleyip ezberlemediklerini kontrol etmek ve gerektiğinde tashihte bulunmaktır. ${ }^{44}$

Yirmi öğrenci arasından seçilen nakibin görevi hakkında vakfiyede herhangi bir bilgi yer almamaktadır. Nakib kelimesi, bir topluluğun durumunu en iyi bilen ve o topluluğa nezaret eden kimse anlamlarına gelmektedir. ${ }^{45}$ Memlük Kahiresi’ndeki bazı ilim kurumlarının günümüze ulaşan vakfiyelerinde nakibin görevi, derste düzeni sağlamak ve derse gelmeyen öğrencilerin kaydını tutmak olarak belirtilmiştir. ${ }^{46}$ Tâceddin es-Sübkî (ö. 771/1370) Muîdün-niam ve mübîdün-nikam adlı eserinde hadis öğrencilerinin yoklama kâtibi (kâtibü gaybetis-sâmiîn) ve onun görevleri hakkında müstakil bir başlık açmış, bu görevlinin vazifesinin, derste hazır bulunanlar ile semâ için bulunanları dikkatli bir şekilde tespit edip kayıt altına almak olduğunu ifade etmiştir. ${ }^{47}$ Çünkü öğrencilerin bir kısmı derste hazır bulunduğu halde dersi dikkatle dinlemeyebilir ve bunun takibini yapmak "kâtibü’l-gaybe"nin görevidir. ${ }^{48} \mathrm{Bu}$ durumda hadis dersi söz konusu olduğunda "nakib" ve "kâtibü’lgaybe" isimlerinin aynı görevliye işaret ettiği söylenebilir. Bu görevli, birer

43 Vakfiyyetü Hüsâmeddîn Lâç̧în, nr. 3/18.

44 Vakfiyyetü Hüsâmeddîn Lâçîn, nr. 3/18.

45 İbn Manzûr, Lisânü̉l-Arab, nkb md.

46 Makdisi, Ortaçă̆’da Yüksek Öğretim, s. 320; Abdülâtî, et-Ta'lîm fî Misr, s. 289.

47 Sübkî, Muîdün-niam, s. 208-209.

48 Hadis derslerinde "hazır bulunanlar" ile "semâ için bulunanlar" arasındaki ayırım, rivayette bulunma ehliyetini haiz olmayan küçük çocuklar ile temyiz çağına ulaşmış öğrencilerin durumlarını birbirinden ayırmak için de vurgulanmış olabilir. Bu durumda nakib, birinci grupta yer alanlar için "huzur kayd»", ikinci grupta yer alanlar için ise "semâ kaydı" yazardı (ayrıntılı bilgi için bk. Özkan, Memlüklerin Son Asrında Hadis, s. 94-95). 
vakıf kurumu olan ilim kurumları için önemliydi, zira geçerli bir mazereti olmaksızın derse gelmeyen öğrencilerin vakıf gelirlerinden pay almaları meşru görülmemekteydi. ${ }^{49}$

Vakfiyenin hadis şeyhi hakkındaki şartlarında ise şeyhin, hadis ilminde rivayet ve dirayet sahibi olması, hadis semâ için tahsil ve rihlelerinin bulunması gerektiği ifade edilmiştir. ${ }^{50}$ Hadislerin usulüne uygun bir şekilde nakledilmesi anlamındaki "rivâyetü'l-hadîs" ilmi yanında "dirâyetü'l-hadîs" terimine ilk defa yer veren müellifin, Memlükler döneminde Kahire'de yaşayan İbnü’l-Ekfânî (ö. 749/1348) olduğu ifade edilmektedir. ${ }^{51}$ Onun ilimler tasnifine dair telif ettiği İrşâdüll-kāsıd ilâ esne'l-makāsıd adlı eserinde yer verdiği dirâyetü'l-hadîs ilmi, senet ve metnin (râvi ve mervî) bütün yönleriyle ele alınmasını ifade etmektedir. Buna göre rivayetler hakkında sahih, hasen, zayıf gibi hükümlerden hangisinin verileceği, haberin semâ, arz ve icazet gibi tahammül yollarından hangisiyle nakledildiği, râvilerin taşıması gereken özellikler (şürûtu’r-ruvât), rivayetteki garip kelimelerin mânalarının tespit edilmesi, musannef, müsned, mu'cem gibi tasnif türlerinin bilinmesi gibi meseleler dirâyetü'l-hadîs ilminin konularını teşkil etmektedir. ${ }^{52}$ İbnü'l-Ekfânînin, İbn Tolun Camii’nin vakfiyesi hazırlanırken Mısır'da ve hayatta olduğu dikkate alındığgnda onun rivâyetü'l-hadîs ve dirâyetü'l-hadîs ilimleri hakkında verdiği bilgilerin, cami vakfiyesinde hadis şeyhi için şart koşulan rivayet ve dirayet bilgisinin mahiyetini anlamaya yardımcı olduğu söylenebilir.

Hadis şeyhine, cami vakfından aylık 200 dirhem, muîde ise 80 dirhem tahsis edilmiştir. Hadis dersindeki yirmi öğrenciye aylık toplam 320 dirhem verilmesi, bu miktarın öğrenciler arasında, onların seviyelerini göz önünde bulundurarak şeyh tarafından paylaştıılması kararlaştırılmıştır. Zikredilen 320 dirhemden nakib olarak görevlendirilen öğrencinin alacağı pay ise vakfiyede 30 dirhem olarak belirlenmiştir. ${ }^{53}$

\section{Tıp Müderrisi ve Öğrencileri}

Camideki tıp dersi için vakfiyede, tıp ilmini (tıbbü’l-ebdân), yani hastalıklar ve tedavi yollarını gerektiği şekilde bilen bir müderris tayin edilmesi

\footnotetext{
49 Makdisi, Ortaçă̆’da Yüksek Öğretim, s. 320.

50 Vakfiyyetü Hüsâmeddîn Lâçîn, nr. 3/18.

51 Çakan, "Dirâyetü'l-hadîs", s. 366-67.

52 Ayrıntılı bilgi için bk. İbnü’l-Ekfânî, İrşâäül-kāsıd, s. 42.

53 Vakfiyyetü Hüsâmeddin Lâçîn, nr. 3/18.
} 
kararlaştırılmıştır. ${ }^{54}$ Tip müderrisi, kendilerine vakıftan tahsisat ayrılan on öğrencisini tıp ilmine dair bilinmesi gereken metinleri ezberlemekle vazifelendirecektir. Ardından onların çalışmalarının düzeltilmesi gereken yerlerini tashih edecek, anlamakta zorlandıkları hususları onlara açıklayacaktır. Müderrise aylık 100 dirhem, on öğrencisine ise aylık toplam 150 dirhem tahsis edilmiş olup müderris diğer derslerde olduğu gibi bu 150 dirhemi öğrencileri arasında kendi katındaki derecelerine göre paylaştıracaktır. ${ }^{55}$

Vakfiyede yer alan öğrencilerin vazifeleri ile ilgili bölüm incelendiğinde camide tıp ilmine dair teorik bir ders yapıldığı anlaşılmaktadır. Tıp derslerinin muhtemelen diğer ilimlerle aynı usulde yani bir hocayla belirli metinler üzerinde çalışarak yapıldı̆̆ 1 düşünülmektedir. ${ }^{56}$ Ayrıca cami dahilinde bîmâristan gibi işlev gören, öğrencilerin öğrendiklerini uygulama imkânı bulduğu ve hastaların tedavi edildiği bir mekânın bulunup bulunmadığ hakkında vakfiyeden ve dönemin diğer kaynaklarından herhangi bir bilgi elde edilememiştir.

\section{Mîâd Şeyhi ve Kāri}

Vakfiyede, zikredilen derslerin yanında camide mîâ meclisleri düzenlenmesi kararlaştırılmış ve bunun için camiye bir mîâd şeyhi ve bir kāri tayin edilmiştir. Mîâdın vaaz ve nasihat içerikli bir ders olduğu anlaşılmaktadır. Bu

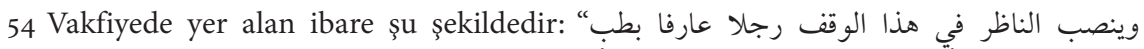
"الأبدان؛ فهو المعرفة للأمراض والأدوية، يجلس بالجامع المذكور للإقراء الطب وتعليمه (Vakfiyyetü Hüsâmeddîn Lâçîn, nr. 3/17, 18).

55 Vakfiyyetü Hüsâmeddin Lâçîn, nr. 3/17.

56 Chamberlain, Ortaçağ’da Bilgi, s. 114. Leiser, İbn Ebû Usaybia’nın (ö. 668/1269) Uyûnül-enbâ' fî̀ tabakâti'l-etıbbâ' adlı eserini temel alarak tıp eğitiminin usulünü ve mahiyetini tespit etmeye çalıștığı makalesinde, tıp öğrencilerinin bir mecliste halka oluşturarak belirli metinleri bir hocadan tahsil ettiklerini, hocanın da metnin hatalı okunduğu yerleri düzelttiğini ve sorulan soruları cevapladığını belirtmektedir (Leiser, "Medical Education in Islamic Lands", s. 59-60). George Makdisi de fakihler tarafından kullanılan "skolastik metod"un tıp ilminde de uygulandığını belirtir ve buna delil olmak üzere VII. (XIII.) yüzyılda yaşadığı bilinen Necmeddin İbnü’l-Lebbûdî isimli âlimin Tedkikk'l-mebâhisit-tıbbiyye fî tahkikkıl-mesâilil-hilâfiyye alâ tarîkı mesâililfukahầ adlı eserini zikreder. Kitabın ismi tıp mesaili üzerine yapılan çalışmalarda, fukahanın fikıh mesailini tedris ederken kullandığı yöntemlerin benimsendiğini ima etmektedir (Makdisi, "The Scholastic Method in Medieval Education", s. 659). Bununla birlikte Ruhâvî (ö. 319/931'den önce) ve Ebû Bekir er-Râzî (ö. 313/925) gibi hekimlerin tıp eğitiminin teorik ve pratik yönünü eşit bir şekilde vurguladıkları bilinmektedir (Leiser, "Medical Education in Islamic Lands", s. 68-69). Bu durum dikkate alındığında İbn Tolun Camiỉnde tıp eğitimi alan öğrencilerin ya camide bulunan bir bölümde ya Kahire'deki bîmâristanlardan birinde ya da tıp müderrisinin uygun gördüğü bir mekânda pratik bir eğitim almış olmaları da mümkündür. 
meclisler, haftanın belirli günlerinde ve belirli yerlerde gerçekleştirildiği için "buluşma yeri ve zamanı" anlamına gelen mîâd ismiyle anılmıştır. ${ }^{57}$ Genellikle bir tefsir, hadis veya rekāik ${ }^{58}$ metninin takip edildiği mîâdlarda bir kāri, mîâd şeyhinin huzurunda metni ona okur, şeyh de okunan bölümler üzerine bir ders ya da vaaz verirdi. ${ }^{59}$

Vakfiyede mîad şeyhinin, Şâfiî mezhebine mensup, fakih ve müftî olup hadis ve dil ilimlerinde ihtisas sahibi olması şart koşulmaktadır. Mîâdların, birinci gün, cuma günü cuma namazından sonra; ikinci gün, pazar günü öğle namazından sonra; üçüncü gün, çarşamba günü öğle namazından sonra olâmak üzere haftanın üç günü düzenlenmesi kararlaştırılmıştır. Mîâd günleri bu şekilde belirlenmiş olmakla birlikte nâzıra meclislerin gün ve saatlerini değiştirebilme yetkisi verilmiştir. Bu bağlamda onun dilerse yaz aylarında mîâları ikindi namazından sonraya alabileceği belirtilmiştir. Mîâd sırasında şeyhin önünde oturup vakfiyede kararlaştırılan konulara dair belirli kitaplardan metin okumak üzere bir kāri de tayin edilmiştir. Buna göre kāri, şeyhin huzurunda bir miktarı tefsirden, bir miktarı hadisten, bir miktarı rekāik kitaplarından, bir miktarı da selef-i sâlihînin sözlerinden olmak üzere Allah'a itaate ve günah işlemekten kaçınmaya teşvik eden metinler okuyacaktır. Cami vakfından mîâd şeyhine aylık 200 dirhem, söz konusu kārie ise 40 dirhem maaş tahsis edilmiştir. ${ }^{60}$

\section{Münşid/Mâdih}

Camiye mîadın akabinde Hz. Peygamber'i öven şiirler (emdâh) inşad etmesi için bir "münşid" de tayin edilmiştir. Vakfiyede münşidin güzel sesli olması şart koşulmuş ve onun görevinin, camide düzenlenen meclislerde ve özellikle de mîâdların akabinde yüksek bir sesle Hz. Peygamber'i metheden şiirler inşad etmek olduğu belirtilmiştir. Cami vakfından münşide aylık 20 dirhem maaş tahsis edilmiştir. ${ }^{61}$

İbn Tolun Camii vakfiyesinde münşid diye anılan bu görevliye Memlükler döneminde mâdih adı da verilmekteydi. Mesela Sultan Hasan Camiìnin vakfiyesinde camiye bir mâdih tayin edilmesi ve onun mîâdın akabinde Bûsîrînin (ö. 695/1296) Kasîdetüll-bürde’si gibi Hz. Peygamber'i öven şiirler

\footnotetext{
57 Özkan, Memlüklerin Son Asrında Hadis, s. 135.

58 Rekāik terimi, züht hayatına dair rivayetler ve bu konuyla ilgili literatürü ifade etmektedir (ayrıntılı bilgi için bk. Özafşar, "Zühd ve Rekāik”, s. 535-37).

59 Berkey, Popular Preaching, s. 38.

6o Vakfiyyetü Hüsâmeddin Lâçîn, nr. 3/17, 18.

61 Vakfiyyetü Hüsâmeddin Lâçîn, nr. 3/17, 18.
} 
(medâih) inşad etmesi kararlaştırılmıştır. ${ }^{62}$ Sübkî, Muîdün-niam'da ulemanın tayin edildiği mansıpları ele alırken münşid için de bir başlık açmıştır. Burada münşidin görevinin, Hz. Peygamber'i öven, Allah Teâlâyı ve onun nimetlerini hatırlatan, ölümden ve sonrasından bahseden şiirler okumak olduğunu belirtmiş, ancak münşid isminin işaret ettiği asıl hususun Hz. Peygamber'i övmek olduğunu özellikle vurgulamıştır. ${ }^{63}$

\section{Kıraat ve Nahiv Mütesaddiri}

Kıraat ve nahiv mütesaddiri ile ilgili vakfiyede yer alan şartları incelemeden önce modern literatürde mütesaddir kelimesinin ne ifade ettiği konusunda bir belirsizlik olduğunu ifade etmek gerekir. ${ }^{64}$ Dönemin kaynaklarına başvurulduğunda da bu belirsizliğin kolaylıkla giderilmesi mümkün görünmemektedir. Mütesaddir teriminin, camide veya başka bir ilim kurumunda tertip edilen ilim meclisinde, ihtisas sahibi olması sebebiyle öne geçen, yani ders veren âlim anlamında kullanıldığı düşünülebilir. Memlükler dönemi söz konusu olduğunda mütesaddir ve tasdîr terimleri çoğunlukla maaşı bir mansıba işaret etmektedir. Zira dönemin ilim kurumlarının vakfiyeleri incelendiğinde mütesaddir kadrosuna yapılan tahsisatı görmek mümkündür. ${ }^{65}$ Öte yandan mütesaddirin ders yapma usulünün, müderris ve şeyhinkinden farklı olup olmadığı hususunda açık bir bilgiye rastlanmamıştır. Hatta Memlükler döneminde inşa edilen Sultan Hasan Camiỉnin 760 (1359) tarihli vakfiyesinde, tıpkı İbn Tolun Camii’nde olduğu gibi kıraat ve dil ilimlerinde ders vermek üzere bir mütesaddir tayin edilmiş, vakfiye metninde bu mansıbı ifade etmek üzere mütesaddir, hâmişte ise "şeyhü’lkıraati's-seb" ibaresine yer verilmiş yani mütesaddir ve şeyh terimleri eş anlamlı olarak kullanılmıştır. ${ }^{66}$

İbn Tolun Camii'nin vakfiyesinde yer alan kıraat ve nahiv dersi ile ilgili şartlara dönülecek olursa burada, mütesaddirin kıraat ilminde mütevâtir olduğu kabul edilen yedi rivayet üzere kıraat (kırâat-i seb) ve nahivde ihtisas sahibi olması şart koşulmaktadır. ${ }^{67}$ Mütesaddirin sabahın ilk vaktinde cami-

62 Emîn, "Mesârifü evkāfi's-Sultân el-Meliki’n-Nâsır", s. 400-401.

63 Sübkî, Muîdün-niam, s. 204-205.

$64 \mathrm{Bu}$ konudaki farklı yaklaşımlar ve yorumlar için bk. Makdisi, Ortaçağ’da Yüksek Öğretim, s. 297-307; a.mlf., İslâmı̇n Klasik Çağında ve Hiristiyan Batida Beşeri Bilimler, s. 328-30; Özkan, Memlüklerin Son Asrinda Hadis, s 93-94.

65 Bir örnek için bk. Emîn, "Mesârifü evkāfi's-Sultân el-Meliki’n-Nâsır", s. 401.

66 Emîn, "Mesârifü evkāfi's-Sultân el-Meliki’n-Nâsır", s. 401.

67 Kıraat ve nahiv ilimlerinin bir arada ele alınıp dersi verecek hocanın her iki ilimde de ihtisas sahibi olmasının şart koşulması dikkat çekicidir. Nahiv ilminin, kurallarının 
de bulunması, kendisine kıraat ve nahiv tahsil etmek için gelen öğrencilere bu ilimleri okutması ( $i k r a ̂ ́)$ istenmekte, yedi rivayete göre kıraat hususunda bu rivayetleri hem tek tek (müfreden) hem de bir arada (cemian) okutması gerektiği ifade edilmektedir. Cami vakfından kıraat ve nahiv mütesaddirine aylık 80 dirhem tahsis edilirken bu dersi takip edecek öğrencilerin sayısı sınırlandırılmamış ve onlara bir tahsisat da ayrılmamıștır. ${ }^{68}$ Dolayısıyla bu dersin, vakıf tarafından desteklenen daimi öğrencileri olmadığı anlaşılmaktadır.

\section{Mülakkın}

İbn Tolun Camii’ne, kıraat ve nahiv mütesaddirine benzer șekilde, Kur'ân-1 Kerim okumayı öğrenmek üzere huzuruna gelen öğrencilere ders verecek bir mülakkın tayin edilmiştir. Mülakkın teriminin kendisinden türediği telkīn mastarı, birine bir söz söyleyip onun o sözü anlamasını ve sözün, onun diline yatkın hale gelmesini sağlamak gibi anlamlara gelmektedir. Telkin (telkin), Kur'an’ın tahammül ve hıfz yollarından biri olarak tanımlanmıştır. Bu anlamda telkin, kişinin Kur'an’ı usulüne uygun bir şekilde okuyup ezberlemek için onun kıraatini bir hocadan dinleyerek öğrenmesi şeklinde de anlaşılabilir. Meşhur kıraat âlimi İbnü’l-Cezerînin (ö. 833/1429) Kahire'de verdiği bu türden derslere çok sayıda insanın katıldığı, bu yüzden onun her öğrenci ile tek tek ders yapamadığı, bunun yerine kalabalık bir gruba bir âyeti okuduğu ardından da bu grubun sesli bir şekilde tek seferde onun okuyuşunu tekrar ettiği kaydedilmiştir. Burada İbnü'l-Cezerînin yaptığı okumayı ifade etmek için telkin, derse katılanların yaptığı tekrarı ifade etmek için ise arz terimleri

tutarlı olduğunu göstermek için kıraat ilminin konusu olan kıraatlere dayandığı, kıraat ilminin de kıraatlerin sahih, fâsit vb. hükmünü belirlemede ve bunlar arasında tercihte bulunmada nahiv ilmine başvurduğu bilinmektedir (İnanç, "Teşekkül Sürecinde Nahiv-Kıraat İlişkisi”, s. 168-77). Nahiv ve kıraat ilimleri arasındaki bu ilişki, İbn Tolun Camiìnde bu iki ilme dair ders vermek üzere bir mütesaddirin tayin edilmiş olmasını açıklayabilir. Aynı mansıp, sadece İbn Tolun Camii’nde değil dönemin diğer bazı ilim kurumlarında da bulunmaktaydı (bazı örnekler için bk. Emîn, "Mesârifü evkāfi's-Sultân el-Meliki’n-Nâsır", s. 401; Abdül'âtî, "Hüccetü vakfi'sSultân el-Müeyyed", s. 337-38).

68 Vakfiyyetü Hüsâmeddin Lâçîn, nr. 3/17, 18. Kıraat ve nahiv mütesaddirinin verdiği derslerde genellikle öğrenci sayısı sınırlandırılmamakta ve öğrencilere tahsisat ayrılmamaktadır. Bir başka deyişle kıraat ve nahiv mütesaddirinin, daimi bir öğrenci topluluğuna değil kendisinden ilim tahsil etmek için gelen bütün öğrencilere ders vermekle görevlendirildiği söylenebilir. Mesela Sultan Hasan Camiỉnin vakfiyesinde hem kıraat ve nahiv dersini veren mütesaddir hem de Kur'an okumayı öğreten mütesaddir, kendilerinden ders almak için gelen her öğrenciye ders vermek üzere görevlendirilmiştir (Emîn, "Mesârifü evkāfi’s-Sultân el-Meliki’n-Nâsır", s. 401). 
kullanılmıştır. ${ }^{69}$ Vakfiyede, İbn Tolun Camiïnde bu dersi verecek olan mülakkına aylık 60 dirhem maaş tahsis edilmiştir. ${ }^{70}$

\section{Şeyhüssübha ve Müsebbihler}

İbn Tolun Camiỉnin Memlükler döneminde yeniden imar edildiği dönemde hayatta olan Ahmed b. Abdülvehhâb en-Nüveyrî (ö. 733/1333), muhtemelen cami vakfiyesini inceleme firsatı bulmuş ${ }^{71}$ ve vakfiyede bulunan dersler ve mansipları Nihâyetüll-ereb fî fünûnil-edeb adlı eserinde özet bir şekilde kayıt altına almıştır. Burada camide, şeyhüssübha denen bir görevlinin bulunduğu ifade edilmektedir. ${ }^{72}$ Bununla birlikte bu eserde, mansıba tayin edilen kişinin yerine getirdiği vazife hakkında bir bilgi bulunmamaktadır. Vakfiyede ise camiye iyilikleriyle mâruf salih iki kişi ile bunların her birinin yanında bulunacak on beşer kişinin zikir tespih etmek üzere vazifelendirildiği belirtilmiştir. Müsebbihlerin zikrin akabinde sultana ve vâkıfa dua etmeleri gerektiği de kayıt altına alınmıştır. ${ }^{73}$ Nüveyrînin şeyhüssübha şeklinde kaydettiği görevli, muhtemelen vakfiyede zikredilen ve otuz müsebbihin zikrini idare eden iki mansıp sahibine işaret etmektedir. Vakfiyede otuz müsebbihin her birine aylık 10 dirhem, iki şeyhüssübhaya ise aylık 30 'ar dirhem maaş tahsis edilmiştir. ${ }^{74}$

İbn Hacer de (ö. 852/1449), Ebü'l-Abbas Ahmed el-Mülessim (ö. 740/133940) adlı âlimin hayatı hakkında bilgi verirken onun, İbn Tolun Camiìnde meşîhatüs-sübha mansıbına tayin edildiğini ve kendisine aylık 30 dirhem maaş tahsis edildiğini ifade etmiştir. ${ }^{75}$ Mansıbın ismi ve mansıp sahibinin aldığı tahsisat hakkındaki bu bilgi, vakfiye metnindeki kayıtlarla örtüşmek-

69 Cermî, Mu'cemü ulûmi'l-Kur'ân, s. 105-106.

70 Vakfiyyetü Hüsâmeddin Lâçîn, nr. 3/18.

71 Nüveyrî, Memlükler döneminde önemli idarî görevler üstlenmiş, Nâsıriyye Medresesi ve Mansûriyye Bîmâristanı gibi prestijli ilim kurumlarının nâzırlığını yapmış bir müelliftir. Onun eserinin çeşitli bölümlerinde ilim kurumlarının vakfiyeleri hakkında ayrıntılı bilgiler verdiği ve yaşadığ 1 döneme ilişkin Memlük arşivlerine dayandığ1 anlaşılan önemli kayıtlar tuttuğu tespit edilmiştir (bk. Muhanna, The World in a Book, s. 57-65, 75, 90-91).

72 Nüveyrî, Nihâyetüll-ereb, XXXI, 203.

73 Vakfiyede, müsebbihlerin tesbihat sırasında "Dilde hafif, mizanda ağır olan ve Rahman’n sevdiği iki söz vardır. Bunlar: 'Sübhânellahi ve bi-hamdihî, sübhânellahi'lazîmdir” hadisinde yer alan "سبحان الله وبحمده، سبحان الله العظيم " ibarelerini zikretmeleri gerektiği belirtilmiştir (Vakfiyyetü Hüsâmeddin Lâç̂in, nr. 3/17, 18; hadis için bk. Buhârî, “Tevhîd", 58).

74 Vakfiyyetü Hüsâmeddin Lâçîn, nr. 3/17, 18.

75 İbn Hacer, ed-Dürerüll-kâmine, I, 198. 
tedir. İbn Hacer'in, Ebü'l-Abbas el-Mülessim'i tasavvuf yoluna giren bir zat olarak anması ve şeyhüssübhânın yanında zikir tespih edenleri “fukara” diye tanımlamasından hareketle camide vazifelendirilen iki şeyhüssübha ve otuz müsebbihin sûfîler arasından tayin edildiğini söylemek mümkündür. ${ }^{76}$

\section{Hatip, İmam, Müezzinler ve Kāriler}

İbn Tolun Camiỉnin vakfiyesinde, hatibin ve imamın sahip olması gereken vasıflarla ilgili şartlar ve bunların tahsisatı kayıt altına alınmıştır. Camiye hatip olarak tayin edilen kişinin, Şâfiî mezhebine mensup, fakih ve hitabet görevini yerine getirmeye ehil olması şart koşulmuştur. Vazifesi cuma namazları, bayram namazları, küsûf günleri ve yağmur duası (istiskā) yapılan günlerde camide hutbe vermek olarak tanımlanan hatibe, aylık 120 dirhem maaş ve günlük belirli bir miktar erzak tahsis edilmiştir. Camide imamlık vazifesine tayin edilen âlime de aylık 110 dirhem maaş ve hatiple aynı miktarda günlük erzak tahsis edilmiştir. ${ }^{77}$

Bunların yanında, silinen kısımlar olduğundan şartları tam olarak belirlenememekle birlikte vakfiyede camideki mansıpların toplu olarak sıraland1ğı bölümde camiye müezzinler, iki reîsülmüezzinîn ve kāriler tayin edildiği tespit edilebilmektedir. ${ }^{78}$ Vakfiyeye göre camide yirmi altı adet müezzin görevlendirilmiş ve bu müezzinler iki gruba ayrılarak her bir grubun başına bir reîsülmüezzinîn tayin edilmiştir. Bunların iki günlük periyotlarla (nevbet) önce bir grup sonra diğer grup olmak üzere sıra ile müezzinlik vazifesini yerine getirdikleri anlaşılmaktadır. Cami vakfından müezzinlerin her birine aylık 27 dirhem, iki reîsülmüezzinîne ise aylık 45’er dirhem maaş tahsis edilmiştir. ${ }^{79}$ Memlükler döneminde Kahire'de camilere çok sayıda müezzinin görevlendirildiği, bunların namaz vakitlerinde ezan okudukları, vakit namazlarında, cuma günleri ve ramazan günlerinde müezzinlik vazifesinin gerektirdiği hususları yerine getirdikleri, bunun dışında adet olduğu üzere belirli vakitlerde zikir ve salalar okudukları anlaşılmaktadır. ${ }^{80}$

76 İbn Hacer, ed-Dürerül-kâmine, I, 197-98.

77 Vakfiyyetü Hüsâmeddin Lâçîn, nr. 3/17, 18.

78 Vakfiyyetü Hüsâmeddin Lâç̧̂n, nr. 3/18.

79 Vakfiyyetü Hüsâmeddin Lâçîn, nr. 3/17, 18.

8o Mesela Sultan Hasan Camii’ne kırk sekiz müezzin ve üç reîsülmüezzinîn tayin edilmiștir. Burada her on altı müezzin bir reîsülmüezzinîn ile birlikte bir grup teşkil etmekte ve bunlar iki gün boyunca müezzinlik vazifesini yerine getirmekte ardından diğer bir grup görevi üstlenmektedir. Vakfiyeye göre on altı müezzin dörde ayrılarak her bir grup caminin bir minaresinde ezan okumaktadır (ayrıntılı bilgi için bk. Emîn, "Mesârifü evkāfi's-Sultân el-Meliki’n-Nâsır", s. 403-404). 
Bunlara ek olarak camiye Kur'an tilavet etmek üzere bir kāriü'l-mushaf ve birden fazla kāri tayin edilmiştir. Vakfiyeye göre kāriü'l-mushaf, sabah namazlarından sonra camide bulunan büyük mushaftan (el-mushafü’l-kebîr) dilediği bir bölümü okuyacak, Kur’an tilavetinin ardından sultan ve devletinin devamı için dua edecektir. Cami vakfından kāriü'l-mushafa aylık 30 dirhem maaş tahsis edilmiştir. ${ }^{81}$ Kāriü'l-mushaftan ayrı olarak camiye hâfız olmaları şart koşulan on altı adet kāri tayin edilmiş olup vakfiyede bunların Kur'an tilavet etmeleri ve tilavetin akabinde sultana dua etmeleri istenmektedir. ${ }^{82}$ Vakfiyenin silinen kısımları sebebiyle bu kārilerin hangi günlerde ve günün hangi saatlerinde Kur'an tilavet ettikleri, bunu ne şekilde icra ettikleri ve tahsisat 1 tespit edilememektedir.

\section{Müeddip, Arîf ve Mektepteki Öğrenciler}

İbn Tolun Camii, Memlükler döneminde Sultan Lâçin tarafından yeniden imar edilirken camiye çocukların eğitimine tahsis edilen bir mektep inşa edilmiştir. Bu mektebe elli çocuğun eğitimiyle ilgilenmek üzere bir müeddip ve bir arîf tayin edilmiştir. Vakfiyede müeddibin haramlardan uzak duran, iyiliği ile mâruf bir kimse olması ve yazısının güzel olması şart koşulmuştur. Müeddibin görevi, çocuklara Kur'ân-1 Kerim’i ve yazı yazmayı öğretmek olarak belirlenirken arîf, müeddibe yardımcı olmakla vazifelendirilmiştir. Cami vakfından müeddibe aylık 50 dirhem, arîfe aylık 30 dirhem maaş, bunun yanında her ikisine bir miktar erzak tahsis edilmiştir. Çocuklara yazı yazacakları levhalar, mürekkep, kalemler ve divitlerin yanında biri yaz diğeri kış için olmak üzere ikişer kıyafet ve günlük erzak verilmesi ile ilgili şartlar da vakfiyede kayıt altına alınmıştır. ${ }^{83}$

İbn Tolun Camii'nin vakfiyesinde eğitim alacak çocukları ifade etmek üzere "eytâm" ibaresine yer verilmiştir. Buradaki kayıtlar yeterince açık olmamakla birlikte bu ibarenin Memlükler dönemi vakfiyelerinde büluğa

81 Vakfiyyetü Hüsâmeddin Lâçîn, nr. 3/17, 18. Benzer şekilde Sultan Hasan Camii’ne de iki kāriü'l-mushaf tayin edilmiştir. Bunlardan biri sabah namazlarından önce Kur'an'dan bir hizip ve belirli sûreler okuyacak, kıraatin ardından Hz. Peygamber'e salatüselam getirip sultan ve bütün müslümanlar için dua edecektir. Diğer kāri ise cuma namazlarından önce insanlar camiye toplandığında Kur'an tilavet edecek ve tilavetin ardından aynı şekilde dua edecektir. Sultan Hasan Camii vakfiyesinde Kur'an tilaveti, salatüselam ve duanın bütün camilerde adet olduğu üzere icra edilmesinin şart koşulması, bu uygulamanın Memlükler döneminde Kahire camilerinde yaygın bir şekilde sürdürüldüğünü ifade etmektedir (ayrıntılı bilgi için bk. Emîn, "Mesârifü evkāfi's-Sultân el-Meliki’n-Nâsır", s. 405-406).

82 Vakfiyyetü Hüsâmeddin Lâçîn, nr. 3/18.

83 Vakfiyyetü Hüsâmeddin Lâçîn, nr. 3/17, 18; Abdül'âtî, et-Ta 'lìm fî Mısr, s. 230. 
ermemiş çocukları ifade etmek üzere kullanıldığı bilinmektedir. ${ }^{84}$ Müeddip ve arîf ile ilgili şartlarda onların ahlakî vasıflarının güzel olmasına özel bir vurgu yapıldığ 1 görülmektedir. Buradan hareketle müeddip ve arîfin, çocuklara Kur'ân-1 Kerim, okuma ve yazı yazma eğitimi vermenin yanında onların terbiyeleri ve ahlakî gelişimleri ile de ilgilendiklerini söylemek mümkündür. ${ }^{85}$

\section{Hâzinülkütüp}

Vakfiyenin bir bölümünde silinen kısımlar sebebiyle bütün ibareler okunamasa da camiye, kitapları muhafaza etmekle vazifelendirilen bir hâzinülkütüp tayin edildiği anlaşılmaktadır. Bu mansıp sahibine cami vakfından aylık 60 dirhem maaş tahsis edilmiştir. Vakfiyede hâzinülkütübün vazifesi, çeşitli ilimlere dair kitapların (kütüb fî sâiri’l-ulûm) bulunduğu kütüphanede (hizânetü'l-kütüb), bu kitapların muhafazası ve tasnifi ile ilgilenmek olarak belirlenmiştir. Hâzinülkütüp ayrıca, ödünç alınan kitapların takibini yapmak, kaybolup zarar görme ihtimallerine karşı gerekli tedbirleri almak durumundaydı. Bu bağlamda kitapları istifade edebilecek kimselere vermesi, ödünç verdiğinde ise zayi olma ihtimaline karşı belirli bir rehin alması şart koşulmuştur. ${ }^{86}$

Vakfiyedeki ibarelerden hâzinülkütübün, okuma yazma bilen, kayıt tutma ve inşa tekniklerine âşinalığı olan, kütüphanede yer alan kitapların muhtevası hakkında bilgi sahibi olan, onları ait oldukları ilme ve konuya göre tasnif edebilen ${ }^{87}$ ve kitap kültürüne âşina olan bir görevli olduğu anlaşılmaktadır. Ayrıca Sübkî, Muîdün-niam'da hâzinülkütübün görevlerinin kitapları muhafaza etmek, kitaplardan dağılmış ve yeniden tertibe ihtiyaç duyanları

84 İbrâhim, "Nassân cedîdân", s. 152-53, 172-73.

85 Sübkînnin Muîdü’n-niam'da "Küttap Muallimi” başlığı altında ele aldığı görevli ile "müeddip" aynı olmalıdır. Sübkî̀ye göre küttap mualliminin görevi, çocuklara önce Kur'ân-1 Kerim'i, ardından hadisleri öğretmesi ve onlara Kur'an’ı levhaya yazma kabiliyetini kazandırmasıdır (bk. s. 238-39).

86 Vakfiyyetü Hüsâmeddin Lâçîn, nr. 3/17, 18; Neşşâr, Tarihu'l-mektebât, s. 83; Swelim, The Mosque of Ibn Tulun, s. 219.

87 Kütüphanedeki kitapları tasnif etme işi, muhtemelen hâzinülkütübün en önemli görevlerinden biriydi. Hirschler' in tespitine göre Mısır ve Şam coğrafyasında kitapların tasnifi ve fihristinin hazırlanması için kullanılan farklı usuller bulunmaktaydı. Bu bağlamda Eyyûbî Dımaşkı’nda kurulan Eşrefiyye Kütüphanesi’nin hâzinülkütübü tarafından hazırlanan fihrist, günümüze ulaşmış olup bu fihristte kitaplar önce alfabetik olarak listelenmiş, ardından her harf altında boyutlarına göre kategorilere ayrılmış ve son olarak da konularına göre tasnif edilmişlerdi (bk. Hirschler, Medieval Damascus, s. 64-67). 
onarmak, onları ehil olmayan kimselere vermemek ve ödünç verirken zenginlere nazaran kitap temin etmeleri daha zor olan kimseleri öncelemek olduğunu ifade etmiştir. Sübkî, kütüphanedeki kitaplar ödünç verilirken rehin bırakılma şartı koşulması hakkında ise şunları söylemektedir:

Vâkıfın, vakfiyede değerini karşılayacak kadar bir rehin bırakılmadan kitabın vakıf dışına çıkarılmasını yasaklayıcı bir şart koşması çokça karşılaşılan bir durumdur. Bu geçerli ve muteber bir şarttır. Dolayısıyla hâzinülkütüp bir rehin olmaksızın kitabı ödünç vermemelidir. ${ }^{88}$

Muîdü’n-niam'da hâzinülkütüp hakkında verilen bu bilgiler, özel olarak İbn Tolun Camii vakfiyesinde yer alan şartların, genelde ise Memlük kütüphanelerindeki işleyişin ve hâzinülkütübün görevlerinin anlaşılması bakımından önemli ipuçları sunmaktadır.

İbn Tolun Camii’nde yer alan kütüphane, muhtemelen Memlükler döneminde caminin yeniden imarı sırasında inşa edilmişti ve vâkıf tarafından kütüphaneye çeşitli ilimlere dair kitaplar vakfedilmişti. Elimizde daha fazla ayrıntı bulunmadığı için vakfiyede geçen çeşitli ilimlerin neler olduğu ve kütüphanedeki kitapların isimleri tespit edilememektedir. Acaba kütüphanede sadece camide tedrisi yapılan fikıh, hadis, tefsir, tıp, kıraat ve dil ilimlerine dair kitaplar mı bulunuyordu? Bunların dışında kelam, felsefe, mantık, âdâb, tarih ve coğrafya gibi ilimlere dair kitaplar da yer alıyor muydu? $\mathrm{Bu}$ ve benzeri soruların, eldeki bilgilerle cevaplandırılması mümkün görünmemektedir. Bununla birlikte vakfiyede kitapların tasnifi işinin özellikle belirtilmiş olması, kütüphanedeki kitapların sayısının hatırı sayılır bir miktara ulaştığına işaret olarak yorumlanabilir. Camide mansıp sahibi olan ulemanın özellikle de müderrislerin ve öğrencilerin bu kütüphaneden diledikleri şekilde istifade edebilme imkânı buldukları ve kütüphanenin, temelde onların ihtiyaçlarını karşılamak üzere vakfedildiği söylenebilir. İstinsah edilerek çoğaltılan kitaplar oldukça pahalı olduklarından âlimlerin ve öğrencilerin çoğu bunları edinmekte zorluk çekmekteydiler. Muhtemelen bu sebeple Memlükler döneminde Kahire'de ilim kurumları, müderrislerine ve öğrencilerine ihtiyaç duydukları kitapları temin etmekte, bunların bakımı ve muhafazasını sağlamak üzere de görevliler istihdam etmekteydiler. ${ }^{89}$

88 Sübkî, Muîdün-niam, s. 206-207.

89 Berkey, The Transmission of Knowledge, s. 196. 


\section{Sââtî}

Vakfiyede camiye, saatleri hesaplamayı bilen ve bu iş için camide bulunan aletleri kullanma kabiliyetine sahip olan bir sââtî tayin edilmiş ve bu görevliye aylık 80 dirhem maaş tahsis edilmiştir. ${ }^{90}$ Sââtî, muhtemelen ay ve yıldızları gözleyerek zamanın, özellikle de namaz vakitlerinin belirlenmesini konu edinen ilm-i mîkât $1^{91}$ bilen bir vazifeliydi. ${ }^{92}$ Dolayısıyla onun, en azından bu konuda belirli bir teorik ve pratik eğitimden geçerek ihtisas sahibi olduğunu söylemek mümkündür. ${ }^{93}$

\section{Değerlendirme ve Sonuç}

İbn Tolun Camiinde ulemaya tahsis edilen mansıpların tamamını bir arada görmek hem Memlükler döneminde caminin ulemaya sunduğu imkânların açık bir şekilde görülmesi hem de ortaya çıan ilim kurumu modelinin daha sağlıklı bir zeminde değerlendirilebilmesi için önemlidir. Ayrıca ulemaya çok sayıda mansıp sunan bir ilim kurumu olarak İbn Tolun Camii, ele alınan dönemde Kahire'de bir istisna mı teşkil ediyordu yoksa çok mansıplı ilim kurumlarının teşekkülü yönündeki güçlü eğilimin bir temsilcisi miydi meselesi de ele alınan dönemde ilim kurumu tasavvurunu anlamak bakımından önem arzetmektedir.

\begin{tabular}{|c|l|c|c|}
\hline \multicolumn{1}{|c|}{ Mansıp adı } & $\begin{array}{c}\text { Mansıp sahibi } \\
\text { adedi }\end{array}$ & Aylık tahsisat \\
\hline 1. & Şâfî̀ fıkıh müderrisi & 1 & 200 dirhem \\
\hline 2. & Şâfiî fıkıh muîdi & 2 & 160 dirhem \\
\hline 3. & Şâfiî fıkıh öğrencisi & 30 & 500 dirhem \\
\hline 4. & Hanefî fıkıh müderrisi & 1 & 200 dirhem \\
\hline 5. & Hanefî fıkıh muîdi & 2 & 160 dirhem \\
\hline 6. & Hanefî fıkıh öğrencisi & 30 & 500 dirhem \\
\hline 7. & Mâlikî fıkıh müderrisi & 1 & 200 dirhem \\
\hline 8. & Mâlikî fıkıh muîdi & 2 & 160 dirhem \\
\hline 9. & Mâlikî fıkıh öğrencisi & 30 & 500 dirhem \\
\hline
\end{tabular}

90 Vakfiyyetü Hüsâmeddin Lâçîn, nr. 3/17, 18.

91 Helvac1 - Onat, "İlm-i Mîkāt", s. 133.

92 Swelim, Memlükler döneminde camide, sââtî tarafından kullanılan ve güneş saatinin yer aldığı bir odanın olduğunu belirtmektedir (bk. Swelim, Ibn Tulun, s. 170-72).

93 Sübkî, "muvakkit" başlığı altında ele aldığı görevlinin ilm-i mîkāt, ilm-i hey'et ve özellikle kıble yönünün tespiti konusunda bilgi sahibi olması gerektiğini ifade etmiştir. Bu bağlamda muvakkit ve saâtînin birbirine yakın mesleklere ya da ihtisas alanlarına işaret ettiği söylenebilir (bk. Muîdün-niam, s. 212-13). 


\begin{tabular}{|c|c|c|c|}
\hline & Mansip ad 1 & $\begin{array}{c}\text { Mansip sahibi } \\
\text { adedi }\end{array}$ & Aylik tahsisat \\
\hline 10. & Hanbelî fıkıh müderrisi & 1 & 200 dirhem \\
\hline 11. & Hanbelî fikıh muîdi & 2 & 160 dirhem \\
\hline 12. & Hanbeli fıkıh öğrencisi & 30 & 500 dirhem \\
\hline 13. & Tefsir müderrisi & 1 & 100 dirhem \\
\hline 14. & Tefsir öğrencisi & 15 & 250 dirhem \\
\hline 15. & Hadis şeyhi & 1 & 200 dirhem \\
\hline 16. & Hadis muîdi & 1 & 80 dirhem \\
\hline 17. & Hadis öğrencisi & 19 & 290 dirhem \\
\hline 18. & Hadis dersinin nakibi & 1 & 30 dirhem \\
\hline 19. & Tip müderrisi & 1 & 100 dirhem \\
\hline 20. & Tıp öğrencisi & 10 & 150 dirhem \\
\hline 21. & Mîâd şeyhi & 1 & 200 dirhem \\
\hline 22. & Mîâdda görevli kāri & 1 & 40 dirhem \\
\hline 23. & Münşid & 1 & 20 dirhem \\
\hline 24. & Kıraat ve nahiv mütesaddiri & 1 & 80 dirhem \\
\hline 25. & Mülakkın & 1 & 60 dirhem \\
\hline 26. & Şeyhüssübha & 2 & 60 dirhem \\
\hline 27. & Müsebbih/zâkir & 30 & 300 dirhem \\
\hline 28. & Hatip & 1 & $\begin{array}{l}120 \text { dirhem + } \\
\text { günlük erzak }\end{array}$ \\
\hline 29. & İmam & 1 & $\begin{array}{l}110 \text { dirhem + } \\
\text { günlük erzak }\end{array}$ \\
\hline 30. & Reîsülmüezzinîn & 2 & 90 \\
\hline 31. & Müezzin & 26 & 702 \\
\hline 32. & Kāriü’l-mushaf & 1 & 30 dirhem \\
\hline 33. & Kāriler & 16 & $?$ \\
\hline 34. & Müeddip & 1 & $\begin{array}{c}50 \text { dirhem + günlük } \\
\text { erzak }\end{array}$ \\
\hline 35. & Arîf & 1 & 30 dirhem \\
\hline 36. & Mektep öğrencisi & 50 & Günlük erzak \\
\hline 37. & Hâzinülkütüp & 1 & 60 dirhem \\
\hline \multirow[t]{2}{*}{38.} & Sââtî & 1 & 80 dirhem \\
\hline & Toplam & 319 & 6,672 dirhem \\
\hline
\end{tabular}

Tablo 1: İbn Tolun Camii'nde ulemaya tahsis edilen mansiplar 
Tabloda görüldüğü üzere Memlükler döneminde İbn Tolun Camii’nde mansıp sahibi olan ulemanın sayısı 300 'ün üzerindeydi ve ulemaya, mahiyetleri birbirinden farklı otuz sekiz adet mansıp tahsis edilmişti. İstisnalar olmakla birlikte Memlükler döneminden önce ilim kurumları ve özellikle medreseler çoğunlukla bir müderrise, belirli sayıda muîde ve öğrenciye tahsisat sunmaktaydı. Ayrıca bu medreselerin bazılarında müderrislerin farklı ilimleri bir arada okuttuğu bilinse de onlar muhtemelen çoğunlukla yalnızca fikıh dersi vermek üzere tayin edilmekteydiler. ${ }^{94}$ Bu bağlamda İbn Tolun Camii, İslam ilim kurumları tarihinde farklı bir tecrübe ortaya koymaktadır. Zira Memlükler döneminde İbn Tolun Camii’nnin vakfı kurulmadan önce dört fikıh mezhebinin yanında tefsir, hadis, tıp, kıraat ve nahiv gibi ilimler için ayrı ayrı dersler ve mansıplar sunan kurumların sayısı oldukça azdır.

Tespit edilebildiği kadarıyla bu tür ilim kurumlarının ilk örneği, İbn Tolun Camii'nin vakfı kurulmadan yaklaşık yarım asır önce Bağdat'ta inşa edilen Müstansıriyye Medresesiddir. 631 (1234) yılında kurulan bu medrese, dört fikıh mezhebi, hadis, tıp, nahiv ve kıraat ilimleri için dersler ve mansiplar sunmaktaydı. ${ }^{95}$ Kahire'de ise bu kurumların ilk örneği, İbn Tolun

94 Makdisi'ye göre müderris, bir mescidin veya medresenin var olan tek kürsüsünü elinde bulunduran hukuk hocasıdır (Makdisi, “Onbirinci Yüzyıl Bağdad’nnda İslâm Eğitim Müesseseleri”, s. 213). Zengîler ve Eyyûbîler döneminde Dımaşk’ta inşa edilen medreselerin de tek bir müderrisi vardı. Bunun tek istisnası Hanefîler ve Şâfiîler için ortak inşa edilen üç medresedir ki bu medreselere biri Hanefî diğeri Şâfiî olmak üzere iki müderris tayin edilmekteydi (ayrıntılı bilgi için bk. Yılmaz, Zengî ve Eyyûbî Dımaşkinda Ulema, s. 73-114). Eyyûbîler döneminde Kahire'de bulunan medreselerin de çoğu tek bir müderris mansıbına sahiptir. Yalnızca dört medrese birden fazla fıkıh mezhebi için inşa edilmiştir ki bunların biri Şâfiî-Mâlikî, ikisi Şâfî̀-Hanefî ve biri de dört fıkıh mezhebi için Eyyûbîler döneminin sonlarında kurulan Sâlihiyye Medresesi'dir (ayrıntılı bilgi için bk. Leiser, The Restoration of Sunnism in Egypt, s. 187375).

95 Makdisi, İslam eğitim müesseselerini dışlayıcı olanlar ve olmayanlar şeklinde ikili bir tasnife tâbi tutmuş, bunlardan birincisi ile tek bir fikıh mezhebine tahsis edilen ve sadece bu fikıh mezhebinin mensuplarını kabul eden müesseseleri, ikincisiyle ise bir mezhep sınırlaması olmaksızın bütün ilimlere ve ilim ehline açık olan müesseseleri kastetmiştir. Cami dışlayıcı olmayan, medrese ise dışlayıcı bir müessese olarak bu tasnifte yerini almıştır. Makdisi'ye göre Bağdat'ta Müstansıriyye Medresesinnin kuruluşuyla eğitim müesseselerinin gelişiminde tam bir daire elde edilmiştir. Buna göre önce dışlayıcı olmayan eğitim kurumları olarak camiler varken daha sonra dıșlayıcı olan medreseler gelmiş ve nihayetinde Müstansıriyye Medresesi ile birlikte yeniden dışlayıcı olmayan müessese modeline dönülmüş, fakat dışlayıcı olan medresenin özelliklerinden de istifade edilmiştir. Çünkü Müstansıriyye Medresesi, tıpkı medrese öncesinde camilerde görüldüğü üzere bütün Sünnî fıkıh mezheplerinin öğrencilerine açıktı, ancak içerisinde her bir fikıh mezhebi kendi dışlayıcı alanına sahipti ve her bir fıkıh mezhebini temsil eden dört fıkıh kürsüsü bulunmaktaydı (ayrıntılı bilgi için bk. Makdisi, “Onbirinci Yüzyıl Bağdad’ında İslâm Eğitim Müesseseleri”, s. 206-13, 255). 
Camii’nin vakfı kurulmadan kısa bir süre önce 684 (1285) yılında inşa edilen Mansûriyye Külliyesidir. Bu kurum dört fikıh mezhebinin yanı sıra hadis, tefsir ve tıp ilimleri için dersler ve mansıplara sahipti. Dolayısıyla sunduğu dersler ve mansıplar bakımından İbn Tolun Camiỉnde görülen ilim kurumu modelinin, caminin vakfı kurulmadan kısa bir süre önce ortaya çıtığını söylemek mümkündür. Bu model daha sonra Erken Memlük dönemi boyunca Hâkim Camii, Nâsıriyye Medresesi, Şeyhûniyye Hankahı ve Sultan Hasan Camii gibi ilim kurumlarında bazı değişikliklerle beraber uygulanmaya devam edecektir.

\begin{tabular}{|l|c|c|c|c|c|c|}
\hline & $\begin{array}{c}\text { Dört fikıh } \\
\text { mezhebinin } \\
\text { müderrisleri }\end{array}$ & $\begin{array}{c}\text { Hadis } \\
\text { şeyhi }\end{array}$ & $\begin{array}{c}\text { Tefsir } \\
\text { şeyhi }\end{array}$ & $\begin{array}{c}\text { Tip mü- } \\
\text { derrisi }\end{array}$ & $\begin{array}{c}\text { Kıraat ve } \\
\text { nahiv mü- } \\
\text { derrisi }\end{array}$ & $\begin{array}{c}\text { Mîâd } \\
\text { şeyhi }\end{array}$ \\
\hline $\begin{array}{l}\text { Müstansiriyye } \\
\text { Medresesi } \\
(631 / 1234)^{96}\end{array}$ & + & + & + & + & + & + \\
\hline $\begin{array}{l}\text { Sâlihiyye Medresesi } \\
(641 / 1243-4)^{97}\end{array}$ & + & + & + & + & + & + \\
\hline $\begin{array}{l}\text { Mansûriyye } \\
\text { Külliyesi } \\
(684 / 1285)^{98}\end{array}$ & + & + & + & + & + & + \\
\hline $\begin{array}{l}\text { İbn Tolun Camii } \\
(697 / 1298)\end{array}$ & + & + & + & & + & + \\
\hline $\begin{array}{l}\text { Hâkim Camii } \\
(703 / 1303)^{99}\end{array}$ & + & + & + & + & + & + \\
\hline $\begin{array}{l}\text { Nâsiriyye } \\
\text { Medresesi } \\
(703 / 1303)^{100}\end{array}$ & + & + & & & + & + \\
\hline $\begin{array}{l}\text { Şeyhûniyye } \\
\text { Hankahı } \\
(756 / 1355)^{101}\end{array}$ & + & + & & + & + \\
\hline $\begin{array}{l}\text { Sultan Hasan Camii } \\
(762 / 1361)^{102}\end{array}$ & + & + & + & + & + \\
\hline
\end{tabular}

Tablo 2: Çok mansıplı ilim kurumu modelinin teşekkülü

96 Avvâd - Cevâd, el-Medresetül-Müstanstriyye, s. 71-74.

97 Makrîzî, el-Hitat, IV/2, s. 485-9o.

98 Makrîzî, el-Hitat, IV/2, s. 513-20.

99 Nüveyrî, Nihâyetü'l-ereb, XXXII, 58-60; Makrîzî, el-Hitat, IV/1, s. 114-16.

100 Nüveyrî, Nihâyetü'l-ereb, XXXII, 41-52; Makrîzî, el-Hitat, IV/2, s. 524-30.

101 Makrîzî, el-Hitat, IV/2, s. 760-64.

102 Emîn, "Mesârifü evkāfi’s-Sultân el-Meliki’n-Nâsır", s. 339-449. 
Bahsi geçen modelin uygulandığı ilim kurumlarının vakıfları çoğunlukla sultanlar tarafından kurulmuştur. Dolayısıyla ulemaya yüzlerce mansıp sunan ve çok sayıda dersin düzenlendiği bu tür büyük ilim kurumlarının kurulması ve finanse edilmesi sultanların desteği ile mümkün olmaktaydı. $\mathrm{Bu}$ açıdan bakıldığında, Memlükler döneminde Kahire'de onlarca ilim kurumunun varlığı bilinmekle birlikte İbn Tolun Camii gibi çok sayıda ders ve mansıba sahip olan prestijli ilim kurumları sinırlı sayıdadır.

İbn Tolun Camii'nin Memlükler döneminde Kahire'de bulunan ilim kurumları arasındaki yüksek konumu, inşâ ve tabakat eserleri üzerinden de takip edilebilir. Kalkaşendî (ö. 821/1418), Subhu'l-a aşẩda sultanın yalnızca çok önemli ve yüksek dereceli müderrislik mansıplarının tayinini yaptığını belirttikten sonra İbn Tolun Camiìndeki müderrisliklerin de bu kapsamda yer aldığını ifade etmektedir. ${ }^{103}$ Bir başka inşâ eseri olan es-Sagrü'l-bâsim'de de ulemanın tayin edildiği dinî vazifelerin anlatıldığı bölümde, İbn Tolun Camii’ndeki müderrislik makamının Şâfiî kādılkudatına tahsis edildiği kaydedilmiştir. ${ }^{104} \mathrm{Bu}$ bağlamda Memlükler döneminde Kahire kādılkudatlığı yapmış âlimlerin biyografileri ve tayin edildikleri ilmî mansıplar tabakatlar üzerinden incelendiğinde İbn Tolun Camii’ndeki müderrisliklerin bunlar arasında önemli bir yer tuttuğu görülmektedir. ${ }^{105}$ Ele alınan dönemde kādılkudatlık vazifesinin, bir âlimin tayin edilebileceği en önemli mansıp olduğu dikkate alındığında kādılkudatlıkla İbn Tolun Camiỉndeki müderrislikler arasında kurulan hususi ilişki, caminin bir ilim kurumu olarak prestijini gösteren karinelerden biri olarak değerlendirilebilir.

İbn Tolun Camii, Memlükler döneminde kurulan vakfı sayesinde birden fazla ilmin tedris edildiği, ulemaya eğitimle ve dinî vazifelerle ilgili çok sayıda mansıbın tahsis edildiği bir ilim kurumu haline gelmiştir. İbn Tolun Camiìnde görülen ilim kurumu modeli ile ilgili vurgulanması gereken önemli hususlardan biri, farklı ilimlerin bir kurumda tedris edilmesini mümkün kılan bu modelin, ulemaya dikkate değer bir ilmî ve sosyal çevre

103 Kalkaşendî, Subhu'l-a ş̧â, III, 409.

104 Sahmâvî, es-Sagrüll-bâsim, I, 407. İbare şu şekildedir: "تدريس جامع ابن طولون وكان مضافا . بقاضي القضاة الشافعية".

105 Erken Memlük döneminde Kahire kādılkudatlarının tayin edildiği ilmî mansıpları tespit etmeye çalışan Joseph Escovitz özellikle Hanefî kādılkudatlarının önemli bir kısmının İbn Tolun Camii’nde müderrislik yaptıklarını belirlemiştir. Ancak Sahmâvînin eserindeki bilgilere erişemediğinden olsa gerek camideki müderrislik mansıbı ile kādılkudatlık mansıbı arasında hususi bir ilişki olmadı̆̆ını iddia etmiştir (bk. Escovitz, The Office of Qâdî al-Qudât, s. 199-201; Kahire kādılkudatlarından İbn Tolun Camii’nnde mansıp sahibi olanların bir listesi için bk. Midilli, Erken Memlük Döneminde Bir İlmî Müessese, s. 170-72). 
sağlamış olduğudur. Camideki derslere katılan çok sayıda müderris ve öğrencinin birbirleri ile irtibat kurdukları, ilmî müzakerelerde bulundukları ve birbirlerinin derslerinden, eserlerinden ve çalıșmalarından istifade ettikleri düşünülebilir ve bu oldukça muhtemeldir. Bu bağlamda İbn Tolun Camii gibi birden fazla derse ve mansıba sahip olan ilim kurumlarının, âlimlerin birbirleri ile şahsî, ilmî ve meslekî bağlar kurabilmeleri için yeni ve önemli imkânlar sunduğu söylenebilir.

İbn Tolun Camiinndeki mansıp sahiplerinin tahsisatı ise iki düzeyde yorumlanabilir. Bunların birincisi, camideki mansıpların kendi aralarında tahsisat miktarları bakımından derecelenmesi ve bu bağlamda değerlendirilmeleridir. Buna göre en yüksek tahsisatı aylık 200 dirhemle fikıh müderrisleri, hadis şeyhi ve mîâd şeyhi almaktadır. Tefsir ve tıp müderrisi aylık 100 dirhem maaş alırken fikıh ve hadis derslerinin muîdleri ile kıraat ve nahiv mütesaddirinin aylık tahsisleri 80 dirhemdir. Mülakkın ve şeyhüssübha ise aylık 60 dirhem maaş almaktadırlar. Bu miktarların ele alınan dönemde ilimler arasında bir hiyerarşiye işaret edip etmediği tartışmaya açı olmakla birlikte camideki mansıpların kendi aralarındaki derecelenmelerine dair bir veri sundukları söylenebilir.

İbn Tolun Camiỉndeki mansıp sahiplerinin tahsisat miktarları ile Memlükler döneminde Kahirede yer alan diğer ilim kurumlarındaki mansıp sahiplerinin tahsisat miktarlarının mukayese edilmesi ise bir başka değerlendirme alanı sunmaktadır. Buradan yola çıkarak İbn Tolun Camii’ndeki mansipların, Memlükler döneminde Kahire'de bulunan diğer ilim kurumlarındaki mansıplara kıyasla konumu tartışılabilir. Ancak bu mukayesenin sağlıklı bir şekilde yapılabilmesi için dirhemin değerinin Memlükler dönemi boyunca gösterdiği dalgalanmaların dikkate alınması gerekmektedir. Bunun yanı sıra farklı vakfiyelerde farklı para birimlerinin (dirhem nukra, dirhem fülûs vb.) kullanıldığı bilinmekte ve bunların birbirlerine dönüştürülmeleri ayrı bir problem teşkil etmektedir. Ayrıca vakfiyede belirlenen miktarların enflasyona ya da vakfın gelirlerindeki artma ve azalmalara göre ne ölçüde değişime uğradığını da takip etmek çoğu zaman mümkün olmamaktadır. ${ }^{106}$ Buna rağmen birbirleri ile yakın zamanda inşa edilmiş bazı ilim kurumlarının ulemaya sunduğu tahsisat miktarları, bahsi geçen problemler akılda tutulmak kaydıyla mukayese edilebilir. Mesela İbn Tolun Camii'nin vakfının kuruluşundan altı yıl sonra inşa edilen Nâsıriyye Medresesỉnde dört fikıh mezhebinin müderrisleri 200’er dirhem maaş almaktaydı. Bu, İbn Tolun Camii’ndeki fikıh müderrislerinin tahsisatı ile aynıdır. Aynı

106 Berkey, The Transmission of Knowledge, s. 77. 
medresenin hâzinülkütübü aylık 30 dirhem maaş alırken İbn Tolun Camii’ndeki hâzinülkütübe bunun iki katı maaş tahsis edilmiştir. ${ }^{107}$ Benzer şekilde İbn Tolun Camiỉnin vakfının kuruluşundan altı yıl sonra yeniden imar edilen ve kendisi için yeni bir vakıf kurulan Hâkim Camii’nde dört fikıh mezhebinin müderrisleri aylık 130'ar dirhem, her bir mezhebin dersi için tayin edilen iki muîd ise 50'şer dirhem maaş almaktaydılar. Bu miktarların, İbn Tolun Camiinndeki fikıh müderrislerinin 200, muîdlerin ise 80'er dirhem olan aylık maaşlarına kıyasla daha az olduğu görülmektedir. ${ }^{108}$ Hâkim Camiìnde aylık 130 dirhem maaş alan mîâd şeyhi, 30 dirhem alan nahiv müderrisi ve yine 30 dirhem alan mülakkın da İbn Tolun Camii’ndeki emsallerine göre daha az tahsisat almaktaydılar. Daha önce de değinildiği üzere dönemin sultanının emri ile vakıfları kurulan Nâsıriyye Medresesi ve Hâkim Camii, İbn Tolun Camii gibi birden fazla derse ve mansıba sahip olan Kahire'nin önde gelen ilim kurumlarındandır. İbn Tolun Camii'ndeki mansıplara ayrılan tahsisatın bu iki kurumdaki mansiplara ayrılan tahsisat ile aynı ya da daha fazla olduğu tespit edilebilmektedir. Dolayssıyla bu veriler, İbn Tolun Camiỉnin, en azından vakfının kurulduğu VII. (XIII.) yüzyılın sonu ile VIII. (XIV.) yüzy1lın başlarında Kahire’nin önemli ilim kurumlarından biri olduğu bulgusunu destekler niteliktedir.

İbn Tolun Camii’nin serüveni, Memlükler döneminde Kahire'deki ilim kurumları hakkında iki temel eğilimi göstermesi bakımından önemlidir. Bunların birincisi, ele alınan dönemde Memlük coğrafyasında bazı önemli camilerin giderek artan bir şekilde vakıf-temelli ilim kurumları haline gelmesidir. Bu camiler, henüz kuruluşlarından ya da yeniden imar edilişlerinden itibaren vakıflarla desteklenen birer ilim kurumu olarak tasarlanmışlardır. Bu yönleriyle camideki belirli bir sütuna ya da mekâna farklı vâkıflar tarafından dersler vakfedilmesi şeklindeki uygulamanın yaygın olarak görüldügü Mısır'daki Amr b. Âs Camii ya da Dımaşk'taki Emeviyye Camii gibi camilerden farklılık arzetmektedirler. Zira bu örneklerde camilerdeki belirli ders halkalarına vakıflar yapılmakta, caminin kendisi bir ilim kurumu olarak vazedilmemektedir. İbn Tolun Camii’nde ise bizzat caminin vakfı onu bir ibadet mahalli olmanın ötesinde bir ilim kurumu olarak sunmaktadır ve İbn Tolun Camii, bu tür ilim kurumlarının Kahire'deki erken ve en önemli örneklerinden biridir. Daha sonra Kahire'de Hâkim Camii, Sultan Hasan Camii ve Müeyyed Camii gibi camiler bu modelin takipçisi olmuşlardır.

İkinci eğilim ise sultanlar ve önde gelen emîrler tarafından kurulan, içerisinde dört fıkıh mezhebi başta olmak üzere hadis, tefsir, tıp, kıraat ve nahiv

107 Nüveyrî, Nihâyetü'l-ereb, XXXII, 47.

108 Nüveyrî, Nihâyetü'l-ereb, XXXII, 59. 
gibi ilimlerin tedris edildiği ve bu ilimlerde ihtisas sahibi olan ulemaya mansıpların sunulduğu ilim kurumlarının teșekkülüdür. Bu kurumlar hem fizikî boyutları hem vakıflarının zenginliği hem de sundukları dersler ve mansıpların çeşitliliği bakımından Kahire'deki emsallerinden daha büyüktüler ve muhtemelen onlar arasinda daha yüksek bir konuma sahiptiler. İbn Tolun Camii de şehirdeki bu önemli ilim kurumlarından biriydi.

İbn Tolun Camii’nin günümüze ulaşan vakfiyesi, Memlükler döneminde Kahire'de ilim kurumlarının işleyişi ve ulemanın ilmî-meslekî pratiklerini anlamak adına önemli bir kaynak konumundadır. Bu bağlamda vakfiyede her bir dersin müderrisinin dersini hangi usule bağlı kalarak sürdüreceğine dair bazı şartların belirlenmesi ve öğrencilerin tahsisatının paylaştırılması işinin müderrise bırakılması gibi hususlar dikkat çekmektedir. Ayrıca vakfiyede yer alan dersler ve mansıp sahipleri ile ilgili şartlar, ilimlerle mansıplar arasında kurulan güçlü bir ilişkiye işaret etmektedir. Vakfiyede fikıh müderrislerinin her birinden, mezhebinin görüşleri ve istikrar kazanmış usullerine göre ders vermesi ve derslerinde mezhebinin delillerini dikkatli bir şekilde sunması istenmekte, tefsir müderrisinin tefsir ilminin yanında irap ve dil ilimlerinde ihtisas sahibi olması şart koşulmakta, hadis şeyhinin hadis ilminde hem rivayet hem dirayet bilgisine sahip olması beklenmekte, kıraat ve nahiv ilimlerinin tedrisi bir arada düşünülmekte ve bu ders için tek bir müderris tayin edilmektedir. Vakfiyedeki şartlarda ilimlerin usulü ve mesailinin dikkate alındığını, şartların ulemanın mevcut tedris usulleri ve ilmî pratikleri ile uyum içerisinde olduğunu söylemek mümkündür.

Vakfiyede belirlenen tahsisat miktarları dikkate alındığında fikıh müderrisliği, hadis şeyhliği ve mîâd şeyhliğinin camideki en yüksek dereceli mansıplar olduğu görülmektedir. Burada mîâd şeyhine verilen önem ve onun fıkıh müderrisi ve hadis şeyhi ile aynı tahsisata sahip olması özellikle dikkat çekicidir. Vaazla karşılaştırıldığında en önemli ayırt edici vasfı bir kitabın takip edilmesi olan mîâdlar, ulema ile toplumu buluşturan, isteyen herkesin katılımına açık olan derslerdi. Mîâdlarda şeyhin yanında belirlenen kitabı şeyhe okuyan bir kāri ve Hz. Peygamber'i metheden şiirler inşad eden bir münşid de bulunmaktaydı. Bir başka deyişle belirlenen bir kitaptan belirli bölümlerin okunması, şeyhin okunan bölümler üzerine kendi ilmî birikimine dayanarak bir ders vermesi ve akabinde münşidin Hz. Peygamberi metheden şiirler inşad etmesi, İbn Tolun Camiỉndeki mîần temel unsurlarıydı. Fakih ve müftî olup hadis ve dil ilimlerinde ihtisas sahibi olması şart koşulan mîâ şeyhinin, vasıfları itibariyle de camideki mansıp sahipleri arasında yüksek bir dereceye sahip oluşu dikkat çekmektedir. 
İşaret edilmesi gereken bir diğer husus ibadet, tedris ve zikir gibi ulema ve toplum için önem arzeden fiillerin İbn Tolun Camiỉnde bir arada yerine getirilmesidir. Bir başka deyişle İbn Tolun Camii, bir cami olması cihetiyle imam, hatip, müezzin ve kāri gibi görevlilere sahip olan şehrin önemli ibadet mahallerinden biriydi. Ancak bunun ötesinde birden fazla ilimde tedris faaliyetinin sürdürüldüğ̈̈, ulemanın ilmî mansıplara sahip olduğu ve bu durumun vakıf hukuku çerçevesinde tanzim edildiği bir ilim kurumuydu. ${ }^{109}$ Bunlara ek olarak sûfîlerden tayin edildiği anlaşılan şeyhüssübha ve müsebbihler aracılı̆̆ı ile de zikirlerin yapıldığı bir tür sûfî kurumuydu. İbn Tolun Camii, Memlükler döneminde Kahire'de bir yanda şehir halkının ibadetlerine devam ettiği, bir yanda çocukların müeddip ve arîften Kur'an ve yazı eğitimi aldığı, bir yanda ulemanın fikıh, tefsir, hadis, tıp, kıraat ve nahiv derslerini sürdürdüğü, bir yanda mîâd şeyhinin kāri ve münşid ile birlikte şehir ahalisine açık dersler verdiği, bir yanda müderrislerin ve öğrencilerin kütüphaneden kitaplar ödünç alıp okuduğu, bir yanda kārilerin Kur’an tilavetinde bulunduğu, bir yanda sûfîlerin şeyhüssübhanın nezaretinde zikir yaptığı ulemanın ve toplumun farklı unsurlarını bir araya getiren çok fonksiyonlu bir ilim kurumuydu.

İbn Tolun Camii’nde ulemaya mahiyetleri birbirinden farklı otuz sekiz mansıp tahsis edilmiştir ve mansıp sahiplerinin sayısı 300'ü aşmaktadır. Bu durum, Memlükler döneminde Kahire'de bir caminin ulemaya sunabileceği mansıpların çeşitliliğini ve mansıp sahiplerinin sayısının çokluğunu göstermesi bakımından özellikle dikkat çekicidir. Bu makalede İbn Tolun Camii ve vakfiyesi üzerine yapılan inceleme ve yorumlar, Memlükler döneminde ilim kurumu dendiğinde işaret edilen müessesenin yalnızca medrese olmadığını ve Kahire'deki bazı büyük camilerin, sultanlar ve yüksek rütbeli emîrler tarafından kurulan vakıflar aracılı̆g ile ulemaya dersler ve mansıplar sunan önemli ilim kurumları haline geldiğini ortaya koymaktadır.

$109 \mathrm{Bu}$ tespit, İbn Tolun Camii’ndeki ilmî faaliyetlerin tamamının vakfiye ile tanzim edildiği ve vakıf tarafından desteklendiği şeklinde anlaşılmamalıdır. Mesela Süyûtî (ö. 911/1505) caminin vakfiyesinde yer alan derslerden bağımsız olarak İbn Tolun Camii’nde hadis imla meclislerini düzenlemiştir (Süyûtî, et-Tehaddüs bi-ni'metillâh, s. 88-89). Ancak bu durum, İbn Tolun Camii için olduğu kadar diğer ilim kurumları ve medreseler için de geçerlidir. Bir başka deyişle Memlükler döneminde vakıflardan bağımsız derslerin düzenlendiği mekânlar yalnızca camiler değildir. Bu bağlamda Belevînin (ö. 780/1378) Kahire'deki bazı medreselerde aldığı dersler dikkate değerdir. Endülüs'ten hac yolculuğu ve ilim tahsili için çıktığı seyahat sırasında kısa bir süre Kahire’ye uğrayan Belevî, burada İmam Şâfîi Türbesi’nin yanındaki medresede ve Nâsıriyye Medresesi’nde bu kurumların vakıfları tarafından desteklenen derslerden bağımsız olarak çeşitli âlimlerden dersler almış, kitaplar okumuş ve bu kitapların icazetlerini almıştır (bk. Belevî, Tâcüll-mefrik, I, 226-30, 236). 


\section{Bibliyografya}

Abdülâtî, Abdülganî Mahmûd, et-Ta'lìm fî Mısr zemene'l-Eyyûbiyyîn ve’l-Memâlîk, Kahire: Dârü'l-maârif, t.y.

Abdülâtî, Abdülganî Mahmûd, "Hüccetü vakfi's-Sultân el-Müeyyed Şeyh el-Mahmûdî", et-Ta'lìm fî Misr zemene'l-Eyyûbiyyîn ve'l-Memâlîk içinde, s. 331-48.

Avvâd, Korkîs - Mustafa Cevâd, el-Medresetüll-Müstansıriyye, Beyrut-London: Dârü'lverrâk, 2008.

Aynî, Bedreddin, İkdü'l-cümân fî târîhi ehlì-zamân: Asru selâtînil-Memâlîk, I-V, nşr. Muhammed Muhammed Emîn, Kahire: Dârü’l-kütüb ve'l-vesâikill-kavmiyye, 2010.

Baybars el-Mansûrî, Zübdetüll-fikre fî târîhi'l-hicre, nşr. D. S. Richards, Beyrut: Matbaatü Müesseseti Hasîb Dirgām ve evlâdih, 1419/1998.

Behrens-Abouseif, Doris, “İbn Tolun Camii”, DİA, 1999, XX, 416-18.

Belevî, Abdullah b. Muhammed, Sîretü Ahmed b. Tolûn, nşr. M. Kürd Ali, Kahire: Mektebetü's-sekāfetidd-dîniyye, t.y.

Belevî, Hâlid b. Îsâ, Tâcüll-mefrik fî tahliyeti ulemâi'l-meşrik, nşr. Hasan es-Sâih, I-II, Muhammediye: İhyâü't-türâsi'l-İslâmî, t.y.

Berkey, J., Popular Preaching and Religious Authority in the Medieval Islamic Near East, Seattle: Washington University Press, 2001.

Berkey, J., Ortaçă̆ Kahire’sinde Bilginin İntikali: İslami Eğitimin Sosyal Tarihi, çev. İsmail Eriş, İstanbul: Klasik Yayınları 2015.

Berkey, J., The Transmission of Knowledge in Medieval Cairo: A Social History of Islamic Education, Princeton: Princeton University, 1992.

Cermî, İbrâhim Muhammed, Mu'cemü ulûmi'l-Kur'ân, Dımaşk: Dârü’l-kalem, 1422/2001.

Chamberlain, M., Ortaçağ’da Bilgi ve Sosyal Pratik: Şam (119o-135o), çev. Büşra Kaya, İstanbul: Klasik Yayınları, 2014.

Çakan, İsmail L., “Dirâyetü'l-hadîs”, DİA, 1994, IX, 366-67.

Emîn, Muhammed Muhammed, el-Evkāf ve'l-hayâtü̉l-ictimâiyye fî̀ Mısr: 648-923/12501517, Kahire: Dârü’n-nehdati'l-Arabiyye, 1980.

Emîn, Muhammed Muhammed, Fihristü vesâikil-Kāhire hattâ nihâyeti asri selâtîni'lMemâlîk, Kahire: Ma'hedü'l-ilmiyyi'l-Fransî li'l-âsâri’ș-şarkıyye bi'l-Kāhire, 1981.

Emîn, Muhammed Muhammed, "Mesârifü evkāfi's-Sultân el-Meliki’n-Nâsır Hasan b. Muhammed b. Kalâvûn alâ mesâlihi'l-kubbe ve'l-Mescidi'l-câmi' ve'l-medâris ve mektebi’s-sebîl bi'l-Kāhire", İbn Habîb el-Halebî, Tezkiretü’n-nebîh fî eyyâmi'l-Mansûr ve benîh içinde, nşr. Muhammed Muhammed Emîn, Kahire 1976-86, Kahire: elHey'etü'l-Misriyyetü'l-âmme li'l-kitâb, 1986, III, 339-49.

Emiroğlu, Nagihan, “Kadınların Hadis Okuttuğu Mekânlar: el-Câmiu’l-Muzafferî Örneği”, İslam Araştırmaları Dergisi, 37 (2017): 33-70.

Escovitz, Joseph H., The Office of Qâdî al-Qudât under the Bahri Mamluks, Berlin: Klaus Schwarz Verlag, 1984.

Haarmann, U., "Mamluk Endowment Deeds as a Source for the History of Education in Late Medieval Egypt", al-Ebhath, 28 (1980): 31-47. 
Helvacı, Mustafa - Yavuz Onat, “İlm-i Mîkāt”, DİA, 200o, XXII, 133-34.

Hirschler, K., Medieval Damascus: Plurality and Diversity in an Arabic Library: The Ashrafiya Library Catalogue, Edinburgh: Edinburgh University, 2016.

İbn Abdüzzâhir, er-Ravzatü'l-behiyyetü'z-zâhire fî hıtati'l-Muizziyyetìl-Kāhire, nşr. Eymen Fuâd Seyyid, Kahire: Mektebetü'd-dâri'l-Arabiyye li'l-kitâb, 1417/1996.

İbn Cübeyr, Rihletü İbn Cübeyr, Beyrut: Dâru Sâdır, 1384/1964.

İbn Dokmak, el-İntisâr li-vâsıtati ikdill-emsâr, nşr. Carl Vollers, Frankfurt am Main: Institute for the History of Arabic-Islamic Science at the Johann Wolfgang Goethte University, 1992.

İbn Dokmak, en-Nüfhatü'l-miskiyye fidd-devleti’t-Türkiyye, nşr. Ömer Abdüsselâm Tedmürî, Sayda: el-Mektebetü'l-asriyye, 1420/1999.

İbn Fazlullah el-Ömerî, Mesâliküll-ebsâr, nşr. Ahmed Abdülkādir eş-Şâzelî, I-XXVII, Ebûzabî: el-Mecmaü’s-sekāfî, 1424/2003.

İbn Hacer el-Askalânî, ed-Dürerü’l-kâmine, nşr. M. Seyyid Câdelhak, I-IV, Kahire: Dârülkütübi'l-hadîse, t.y.

İbn İyâs, Bedâiu'z-zühûr, nşr. M. Mustafa, I-V, Kahire: el-Hey'etü'l-Mısriyyetü'l-âmme li'lkitâb, 1982.

İbn Kādî Şühbe, et-Târîh, nşr. Adnân Dervîş, I-IV, Dımaşk: el-Ma'hedü’l-ilmüyyü’l-Fransî li'd-dirâsâti'l-Arabiyye, 1977-97.

İbn Kesîr, Ebü’l-Fidâ, el-Bidâye ve’n-nihâye, nşr. Abdullah b. Abdülmuhsin et-Türkî, I-XXI, Cîze: Hecer li’t-tıbâa ve’n-neşr ve’t-tevzî́ ve'l-i'lân, 1417-20/1997-99.

İbn Manzûr, Lisânül-Arab, I-XV, Beyrut: Dâru Sâdır, t.y.

İbn Tağrîberdî, el-Menhelü’s-sâfî̀ ve’l-müstevfî ba'de'l-Vâfî̀, nşr. Muhammed Muhammed Emîn, I-XIII, Kahire: el-Hey'etü’l-Misriyyetü'l-âmme li'l-kitâb, 1984-2009.

İbn Tağrîberdî, en-Nücûmüz-zâhire fî mülûki Mısr ve'l-Kāhire, I-XVI, Kahire: Vizâretü’ssekāfe ve'l-irşâd, t.y.

İbnü'l-Ceyân, Şerefeddin Yahyâ b. Şâkir, et-Tuhfetü's-seniyye bi-esmâi'l-bilâdi'l-Mısriyye, Kahire: Mektebetü'l-külliyâti'l-Ezheriyye, 1394/1974.

İbnü’l-Ekfânî, İrşâdü'l-kāsıd ilâ esne'l-makāsıd, nşr. J. Justus Witkam, Leiden: Ter Lugt Pers, 1989.

İbrâhim, Abdüllatîf, “Nassân cedîdân min vesîkati'l-Emîr Sargatmış”, Mecelletü Külliyeti'lâdâb, 27 (1965): 121-58; 28 (1966): 143-200.

İnanç, Yonis, Teşekkül Sürecinde Nahiv-Kıraat İlişkisi, İstanbul: Marmara Üniversitesi İlâhiyat Fakültesi Vakfı Yayınları, 2016.

Kalkaşendî, Subhu'l-a ş̧â, nşr. M. Hüseyin Şemseddin v.dğr., I-XV, Beyrut: Dârü'l-kütübi'lilmiyye, $1407 / 1987$.

Kılıç, Hulusi, "Belâgat”, DİA, 1992, V, 380-83.

Leiser, G., The Restoration of Sunnism in Egypt: Madrasas and Mudarrisun 495-647/11011249 (doktora tezi), University of Pennsylvania, 1976.

Leiser, G., "Medical Education in Islamic Lands from the Seventh to the Fourteenth Century", Journal of the History of Medicine and Allied Sciences, 38/1 (1983): 48-75. 
Little, Donald P., "The Use of Documents for the Study of Mamluk History", Mamluk Studies Review, 1 (1997): 1-13.

Makdisi, G., The Rise of Colleges: Institutions of Learning in Islam and the West, Edinburgh: Edinburgh University Press, 1981.

Makdisi, G., "The Scholastic Method in Medieval Education: An Inquiry into Its Origins in Law and Theology", Speculum, 49/4 (1974): 640-61.

Makdisi, G., “Onbirinci Yüzyıl Bağdad’ında İslâm Eğitim Müesseseleri”, İslâm’ın Klasik Çağında Din Hukuk Eğitim, çev. Hasan Tuncay Başoğlu, İstanbul: Klasik Yayınları, 2007, s. 203-72.

Makdisi, G., İslâm’n Klasik Çă̆ında ve Hıristiyan Batida Beşeri Bilimler, çev. Hasan Tuncay Başoğlu, İstanbul: Klasik Yayınları, 2009.

Makdisi, G., Ortaçağ’da Yüksek Öğretim, trc. Ali Hakan Çavuşoğlu - Hasan Tuncay Başoğlu, İstanbul: Klasik Yayınları, 2012.

Makrîzî, el-Hitat: el-Mevâiz ve'l-i'tibâr fî zikri'l-hıtat ve'l-âsâr, nşr. Eymen Fuâd Seyyid, I-IV, London: Al-Furqan Islamic Heritage Foundation, 1434/2013.

Makrîzî, es-Sülûk li-ma'rifeti düvelil-mülûk, nşr. M. Abdülkādir Atâ, I-VIII, Beyrut: Dârü'lkütübi'l-ilmiyye, 1417/1997.

Midilli, Muhammet Enes, Erken Memlük Döneminde Bir İlmî Müessese: İbn Tolun Camii (1296-1382) (yüksek lisans tezi), Marmara Üniversitesi Sosyal Bilimler Enstitüsü, 2017.

Muhanna, E., The World in a Book: Al-Nuwayri and the Islamic Encyclopedic Tradition, Princeton: Princeton University Press, 2018.

Neşşâr, Seyyid Seyyid, Târîhu'l-mektebât fî̀ Mısr: el-Asrü'l-Memlûkî, Kahire: ed-Dârü'lMisriyyetü'l-Lübnâniyye, 1413/1993.

Nüveyrî, Ahmed b. Abdülvehhâb, Nihâyetü’l-ereb, XXXI, nşr. Necîb Mustafa Fevvâz Hikmet Kişlî Fevvâz, XXXII, nşr. İbrâhim Şemseddin, Beyrut: Dârü’l-kütübi'l-ilmiyye, $1424 / 2004$.

Özafşar, Mehmet Emin, “Zühd ve Rekāik”, DİA, 2013, XLIV, 535-37.

Özkan, Halit, Memlüklerin Son Asrında Hadis: Kahire (1392-1517), İstanbul: Klasik Yayınları, 2012.

Pedersen, J. "'Masdjid”, EI: First Encyclopaedia of Islam,Leiden: E.J. Brill, 1987, V, 354-76.

Raymond, A., "al-Maqrīzīs Khitat and the Urban Structure of Mamluk Cairo", Mamluk Studies Review, 7/1 (2003): 145-67.

Safedî, A'yânü’l-asr, nşr. Ali Ebû Zeyd v.dğr., I-IV, Beyrut-Dımaşk: Dârü'l-fikr, 1418/1998.

Safedî, el-Vâfî bi'l-vefeyât, nşr. Ahmed el-Arnaût - Türkî Mustafa, I-XXIX, Beyrut: Dâru ihyâi't-türâsi'l-Arabî, 1420/200o.

Sahmâvî, Şemseddin Muhammed, es-Sagrü̉l-bâsim fî sınâati'l-kâtib ve’l-kâtim, nşr. Eşref M. Enes, I-II, Kahire: Dârü'l-kütüb ve'l-vesâiki'l-kavmiyye, 1430/2009.

Shaaban, M. Hafez, Piety and Power: Pious Endowments in the Bahrī Mamlūk Period, 12501382 (yüksek lisans tezi), The American University in Cairo, 2015.

Sübkî, Tâceddin, Mu'îdün-ni'am: Makam ve Meslek Ahlâkı, çev. Harun Yllmaz - Muhammet Enes Midilli, İstanbul: Türkiye Yazma Eserler Kurumu Başkanlığı Yayınları, 2019. 
Süyûtî, Hüsnü̉l-muhâdara fî târîhi Mısr ve'l-Kāhire, nşr. M. Ebü’l-Fazl İbrâhim, I-II, Kahire: Dâru ihyâi'l-kütübi'l-Arabiyye, 1387/1967.

Süyûtî, et-Tehaddüs bi-ni'metillâh, nşr. E. M. Sartain, Cambridge: Cambridge University Press, 1975.

Swelim, T., The Mosque of Ibn Tulun: A New Perspective (doktora tezi), Harvard University, 1994.

Swelim, T., Ibn Tulun: His Lost City and Great Mosque, Kahire: The American University in Cairo Press, 2015.

Tücîbî, Müstefâdürr-rihle ve'l-igtirâb, nşr. Abdülhâfız Mansur, y.y.: ed-Dârü’l-Arabiyye lìlkitâb, t.y.

Vakfiyyetü Hüsaimeddîn Lậ̂in (21 Rebiülâhir 697), Dâru'l-vesâiki'l-kavmiyye, Mecmûatü'lMahkemeti'ş-şer'iyye, nr. 3/17, 18.

Yılmaz, Harun, Zengî ve Eyyûbî Dımaşkinda Ulema ve Medrese (1154-1260), İstanbul: Klasik Yayınları, 2017.

Yiğit, İsmail, “Hitat”, DİA, 1998, XVII, 401-402.

Zehebî, Mu'cemü şüyûhi'z-Zehebî, nşr. Rûhiyye Abdurrahman es-Süyûfî, Beyrut: Dârü’lkütübi'l-ilmiyye, 1410/199o.

\section{An Institution of Learning in the Mamluk Period: The Mosque of Ibn Ṭūlūn and Its Stipendiary Positions for Ulama}

The city of Cairo in the Mamluk period was home to numerous educational institutions that offered courses and stipendiary positions (manșibs) to ulama. In this period, some of the great mosques in the city had become waqf-based learning institutions through the waqfs founded by the sultans and high-ranking amirs. The Mosque of Ibn Ṭūlūn, one of these early mosques, was built by Aḥmad b. Țūlūn in 265 (879) in the Țūlūnid city of Qatā'í. After remaining in a dilapidated state during the Ayyūbid and the early Mamluk periods, the mosque was rebuilt at the end of the 7th (14th) century by al-Malik al-Manșūr Ḥusām al-Dīn Lāchīn, the Mamluk sultan. The endowment deed (waqfiyya), which turned the mosque into a prominent learning institution in Mamluk Cairo, was established during the rebuilding process. This article explores the waqf, lessons taught in the mosque, manșibs assigned to ulama in the waqfiyya, definitions of these manșibs, relations established between manșibs and sciences, and the effect of these manșibs on the ulama's scholarly and professional activities.

Having survived through the present, the waqfiyya of the Mosque of Ibn Țülūn is a critical source for understanding the organization of learning institutions and scholarly professional practices of ulama in the Mamluk period. According to the waqfiyya, the courses about the four schools of law (madhhabs), together with the courses in tafsīr, hadìth, medicine, mīād, qiräàa, and naḥw, were organized in the mosque. Additionally, manșibs related to educational and religious duties, such as mudarris of fiqh, mu'ìd, shaykh of tafsìr, shaykh al-hadìth, naqïb, mudarris of medicine, shaykh of mīād, munshid/mādiḥ, mutașaddir al-qirāāa and nạ̣w, 
mulaqqin, shaykh al-subḥa, musabbiḥ/dhākir, khațīb, imām, ra’īs al-mu’adhdhinīn, mu'adhdhin, qārī, mu'addib, 'arīf, khāzin al-kutub, sāāàī, were given to ulama. This article endeavors to identify the meanings of these manșibs by inquiring into the waqfiyya; further, the article also considers surviving waqfiyyas from the educational institutions in Mamluk Cairo, the information in the Mamluk sources, and the discussions on the definitions of manșibs in modern literature. Furthermore, the monthly stipends paid to mansib-owners have been detected through the waqfiyya. Based on this information, this article shows how the manșibs in the Mosque of Ibn Țūlūn were comparatively ranked.

Moreover, the clauses in the waqfiyya related to the qualifications of mansibowners and the procedures for the courses are compared with the other waqfiyyas of the period. Within the waqfiyya, it is stipulated that the mudarris of fiqh should offer his courses with respect to the legal ideas and the established methods (alrasm al-mu'täd) of his madhhab. It is also expected of the mudarris to present the proofs (adilla wa barāhin) of his madhhab to the students. As for mudarris of tafsir, he must be an expert of Qur'anic exegesis as well as linguistics and ir $r a \bar{b}$, while the mudarris of hadith should have the knowledge of both riwayya and dirāya in the science of hadìth. In addition, qirāa and naḥw are included under a single course, and for this course, only one mudarris, namely mutasaddir, is to be assigned. Based on this information, it is suggested that the principles (ușū $l$ ) and questions (masä'il) of the sciences were taken into consideration while determining the clauses of the waqfiyya, which were consistent with the existing learning practices of the ulama.

The trajectory of the Mosque of Ibn Țūlūn is significant in terms of discerning the two particular trends of the institutions of learning in Mamluk Cairo. First, some prominent mosques in the city had gradually become waqf-based learning institutions during the period under consideration. These mosques, since their establishment or reconstruction, had been designed as learning institutions supported by waqfs. In this respect, they differ from mosques like the Mosque of 'Amr b. al-' Aș in Egypt or the Umayyad Mosque in Damascus, where the practice of endowing courses to a certain column or place in the mosque was common. In these examples, endowments were made only for certain study circles (halqa) in the mosques, and the mosque itself was not intended as a learning institution. However, the waqfiyya of the Mosque of Ibn Țülūn presents the mosque as a learning institution rather than simply a place of worship. In this respect, the mosque is an early and significant example of such learning institutions in Mamluk Cairo.

The second pattern is the formation of learning institutions, established by the sultans and leading amirs, where courses were taught primarily on the four madhhabs, ḥadìth, tafsīr, medicine, mīād, qirāa, and naḥw, and where manșibs were offered to ulama who were specialists in these subjects. These institutions were larger than their equivalents in Mamluk Cairo in terms of their physical size, the wealth of their waqfs, and the variety of courses and mansibs they offered. Additionally, they probably also occupied a higher position among these institutions. The Mosque of Ibn Țūlūn was one of the most significant of these learning 
institutions in the city. According to the waqfiyya, there were over three hundred manșib-owners in the mosque, and thirty eight different types of manșibs were given to ulama. This information is particularly noteworthy in that it shows the diversity of mansibs that a mosque in Cairo could offer to the scholars in the Mamluk period, as well as the significant number of manșib-owners. Before the Mamluk period, learning institutions, and particularly madrasas, had offered stipends mostly to only one mudarris and to a select number of students. In this context, the Mosque of Ibn Țūlūn presents a distinct experience in the history of Islamic learning institutions. Thus, this article evaluates the formation of a learning institution model, as was the case for the Mosque of Ibn Țūlūn, in which four madhhabs and more than one science were taught and a large number of manșibs were offered to ulama. In this way, this article attempts to identify the history and context of this institutional learning model, as exemplified by the case of the Mosque of Ibn Ṭūlūn.

Keywords: The Mosque of Ibn Țūlūn, mosque, waqfiyya, manșib, ulama, madrasa, Cairo, Mamluks. 